\title{
Novel Agents Targeting Bioactive Sphingolipids for the Treatment of Cancer
}

\author{
A. Adan-Gokbulut ${ }^{\#}$, M. Kartal-Yandim ${ }^{\#}$, G. Iskender ${ }^{\#}$ and Y. Baran* \\ İzmir Institute of Technology, Department of Molecular Biology and Genetics, Urla, İzmir, Turkey
}

\begin{abstract}
Sphingolipids are a class of lipids that have important functions in a variety of cellular processes such as, differentiation, proliferation, senescence, apoptosis and chemotherapeutic resistance. The most widely studied bioactive shingolipids include ceramides, dihydroceramide (dhCer), ceramide-1-phosphate (C1P), glucosyl-ceramide (GluCer), sphingosine and sphingosine-1-phosphate (S1P). Although the length of fatty acid chain affects the physiological role, ceramides and sphingosine are known to induce apoptosis whereas C1P, S1P and GluCer induce proliferation of cells, which causes the development of chemoresistance. Previous studies have implicated the significance of bioactive shingolipids in oncogenesis, cancer progression and drug- and radiation-resistance. Therefore, targeting the elements of sphingolipid metabolism appears important for the development of novel therapeutics or to increase the effectiveness of the current treatment strategies. Some approaches involve the development of synthetic ceramide analogs, small molecule inhibitors of enzymes such as sphingosine kinase, acid ceramidase or ceramide synthase that catalyze ceramide catabolism or its conversion to various molecular species and S1P receptor antagonists. These approaches mainly aim to up-regulate the levels of apoptotic shingolipids while the proliferative ones are down-regulated, or to directly deliver cytotoxic sphingolipids like short-chain ceramide analogs to tumor cells. It is suggested that a combination therapy with conventional cytotoxic approaches while preventing the conversion of ceramide to S1P and consequently increasing the ceramide levels would be more beneficial. This review compiles the current knowledge about sphingolipids, and mainly focuses on novel agents modulating sphingolipid pathways that represent recent therapeutic strategies for the treatment of cancer.
\end{abstract}

Keywords: Bioactive sphingolipids, cancer, ceramides, ceramide synthase, ceramide kinase, drug resistance, glucosylceramide, glucosylceramide synthase, sphingosine kinase-1, sphingosine-1-phosphate, sphingosine-1-phosphate receptor, cancer treatment.

\section{INTRODUCTION}

Sphingolipids (SLs) are important constituents of eukaryotic cells and are also found in the bacterial genus Sphingomonas. They are composed of an amide-linked fatty acid chain and amino alcohol sphingosine base. Various groups linked to the sphingosine backbone determine the type of the sphingolipid. Since their discovery by J. L. W. Thudichum in 1876, sphingolipids have been considered to be essential solely for structural purposes in cells. However, intensive research showed that they have major roles in signaling events that regulate various cellular activities [1-3]. Ceramide (Cer) and sphingosine-1-phosphate (S1P) are the two main sphingolipids, and are involved in important cellular processes such as cell proliferation [4], differentiation [2, 5], apoptosis [6], motility [7], angiogenesis [8], protein synthesis [9], stress responses [10, 11], carbohydrate metabolism [12], and intracellular trafficking [12]. Other widely studied sphingolipids include dihydroceramide (dhCer), ceramide-1-phosphate (C1P) and sphingosine (Sph) [13, 14]. Ceramide and sphingosine are typically known to induce cell growth arrest and cell death whereas other glycosylated or phosphorylated elements of sphingolipid family including S1P or C1P influence cellular proliferation, survival and drug resistance. As sphingolipids are involved in the regulation of important signalling pathways, altered sphingolipid metabolism may cause pathologic conditions and contribute to cancer progression [15]. Previous studies have shown the significance of bioactive sphingolipids in oncogenesis, cancer progression and drug- and radiation-resistance [16]. Therefore, targeting the elements of sphingolipid metabolism appears to be important for the development of novel therapeutics. This review compiles the current knowledge about sphingolipid metabolism and cellular roles of bioactive sphingolipids, and mainly focuses on novel agents modulating sphingolipid pathways that represent recent therapeutic strategies for the treatment of cancer. Recent evidences explaining the roles of these lipids in

*Address correspondence to this author at the İzmir Institute of Technology, Science Faculty, Department of Molecular Biology and Genetics, Urla, 35430, İzmir Turkey; Tel: +90 232 7507515; Fax: +90 232 7507509; E-mail: yusufbaran @iyte.edu.tr, iytecancer@gmail.com

\#These authors contributed equally. tumorigenesis, tumor development and cancer therapeutics will be discussed.

\subsection{Sphingolipid Metabolism}

Ceramide is the central element of sphingolipid metabolism and is composed of a long-chain sphingoid base, sphingosine, containing various numbers of carbon atoms in combination with a fatty acid chain. It is known that different stimuli such as interleukin (IL)-1, tumor necrosis factor- $\alpha$ (TNF- $\alpha$ ), Fas ligand, ionizing radiation [17], oxidative stress [18], and chemotherapeutics [19] induce the production of ceramide. Ceramide can be generated by two major mechanisms Fig. (1). The first one is the de novo pathway, an anabolic pathway, which takes place on the cytosolic surface of the endoplasmic reticulum (ER) and possibly in the perinuclear membrane and mitochondria-associated membranes known as ERassociated membranes [20]. In this pathway, ceramide is firstly synthesized from serine and palmitoyl-CoA to form 3-ketodihydrosphingosine through the action of serine palmitoyltransferase (SPT) [21-24]. Subsequent steps involve the conversion of 3keto-dihydrosphingosine to dihydrosphingosine (sphinganine) which is then $\mathrm{N}$-acylated to dihydroceramide (dhCer) or Cer by dhCer synthases [25]. Six mammalian genes that encode (dh)Cer synthase have recently been cloned and called longevity assurance homolog-1 of yeast Lag1 (LASS1-6)/Cer synthase (CerS1-6). Different CerS genes are responsible for the synthesis of different length of ceramides. CerS1, for example, synthesizes C18ceramide, whereas CerS2 and CerS4 induce the production of C24and C22- ceramides, respectively [26]. DhCer is then desaturated by dhCer desaturase, to generate $\mathrm{Cer}$ in the last step of de novo synthesis pathway [20,27].

Another mechanism known as the "sphingomyelin cycle" is responsible for the production of ceramide [28] and involves the hydrolysis of plasma membrane sphingomyelin (SM) to ceramide and phosphorylcholine through the action of sphingomyelinase (SMase) enzyme [29-31]. Various SMases have been characterized according to their $\mathrm{pH}$ optima and subcellular localization: lysosomal acid SMase (aSMase), neutral magnesium-dependent SMase (nSMase), zinc-dependent secretory SMase, and alkaline SMase [32]. There is evidence suggesting that stimulation of neutral and acidic SMases has a major role in cell cycle arrest and apoptosis $[33,34]$. The best 


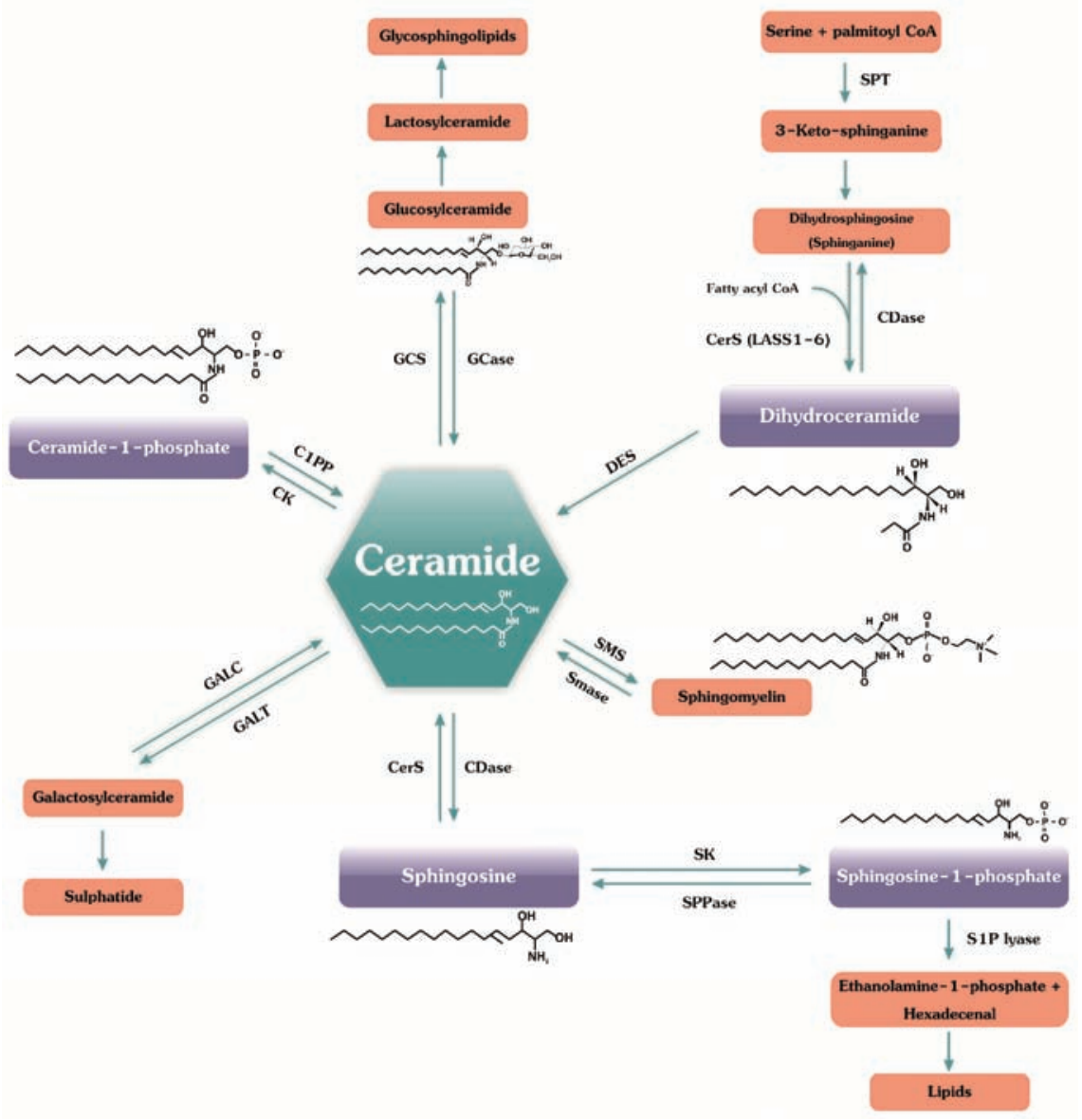

Fig. (1). Bioactive sphingolipid metabolism. CerS (LASS), ceramide synthase; CDase, ceramidase; DES, dihydroceramide desaturase; SMS, sphingomyelin synthase; SMase, sphingomyelinase; GCS, glucosyl-ceramide synthase; GCase, glucosyl ceramidase; CK, ceramide kinase; S1P, sphingosine-1-phosphate; SPPase, S1P phosphatase; SK, sphingosine kinase; C1PP, ceramide-1-phosphate phosphatase.

identified enzyme is lysosomal A-SMase, the deficiency of which causes Niemann-Pack disease types A and B. Sphingomyelin synthase can also be catalyzed producing sphingomyelin from ceramide in a process where phosphatidylcholine is used and diacylglycerol is liberated [35]. For SM production, ceramide is transported from the ER to the Golgi by a ceramide transfer protein (CERT) [36, 37].

Ceramide can also be generated by the breakdown of glycosphingolipids, a mechanism called the "salvage pathway". In this mechanism, the terminal hydrophilic portions of glycosphingolipids are sequentially removed and catalyzed by a series of specific hydrolases. Glucosylceramide (GluCer) and galactosylceramide (GalCer) are the intermediate products which are subsequently hydrolyzed by specific $\beta$-glucosidases and galactosidases to produce Cer [38]. GluCer is generated by GluCer synthase (GCS) in the Golgi, which serves as a precursor for the synthesis of complex glycosphingolipids in the same subcellular compartment [39]. In this reaction, ceramides are carried from ER to Golgi by vesicle budding without the support of a protein transporter [40]. However, the synthesis of complex glycosphingolipids (e.g. gangliosides) occurs in the luminal side of the Golgi. Therefore, the transport of GluCer from the cytosolic surface to the inside of the Golgi is carried out by the ABC transporter, P-glycoprotein (also known as MDR1) [41]. GluCer can be converted back to ceramide by glucosylceramidase [42].

Ceramide produced through the de novo pathway or sphingolipid recycling can be reversly catalyzed into sphingosine by ceramidases (CDase) [43, 44]. Similar to SMases, CDases have also been classified according to their $\mathrm{pH}$ optimum and subcellular localization as acid CDases, neutral CDases and alkaline CDases [45]. Sphingosine is a bioactive lipid, which promotes apoptosis or inhibits cell proliferation, depending upon the cell type [46]. Sphingosine is then phosphorylated by sphingosine kinase-1 and -2 (SK-1 and SK-2) producing the mitogenic signalling lipid, sphingosine-1phosphate (S1P) [47]. Sphingolipids including ceramide, sphingosine and S1P can be converted back to sphingosine by lipid phosphatases $[48,49]$. Additionally, S1P can be irreversibly cleaved by the enzyme S1P lyase (SPL) to generate non-sphingolipids, ethanolamine phosphate and hexadecenal [50]. This step is the only exit pathway from the sphingolipid pathways.

\subsection{Cellular Roles of Bioactive Sphingolipids}

Ceramide is the most studied bioactive sphingolipid and is mainly known to be a tumor-suppressor lipid acting not only in intracellular but also in extracellular processes. Cer is best known to be involved in programmed cell death (apoptosis). Additionally, it is reported to influence the regulation of cell growth, differentiation [28], proliferation [51], senescence [52], and necrosis [53]. In order to exert regulative functions in the cellular processes, ceramides interact with protein kinases and phosphatases. Long-chain ceramides activate protein phosphatase-1 (PP1) and protein phosphatase-2A (PP-2A), which are therefore known as ceramide-activated protein phosphatases (CAPPs) [54]. Activated CAPPs are responsible for transmitting the signal to downstream targets including retinoblastoma protein (Rb), cyclin-dependent kinases (CDKs) and Bcl-2 family members $[55,56]$. Ceramide induces intrinsic apop- 
totic pathway via the regulation of cytochrome c release and the loss of mitochondrial membrane potential [57]. Furthermore, ceramides are known to affect Akt [21], protein kinase C (PKC) [58], phospholipase D, raf-1 [59], and the kinase-suppressor of Ras [60], and significantly alter the level of phosphorylation of various key substrates. Cathepsin D is known to be a binding target for Cer, which may control the actions of lysosomally generated Cer [61].

Most chemotherapeutic drugs have been shown to increase the levels of ceramide and subsequently, endogenous ceramide produced after cytotoxic stimuli and chemotherapy treatment induces apoptosis. In a study by Bose et al. [19], daunorubicin-induced apoptosis of leukemia cells was observed due to increased levels of ceramide. In another study, elevated levels of ceramide and sphinganine were observed in HL60 leukemia cells following treatment with $\mathrm{H}_{2} \mathrm{O}_{2}$ [62]. Combination of paclitaxel and tamoxifen was shown to increase ceramide levels and overcome drug resistance in ovarian adenocarcinoma [63]. Defective generation of ceramide caused resistance of PC3 prostate cancer cells to chemotherapy [64].

An alternative way to elevate the levels of endogenous ceramide within the cell via anticancer agents is administration of exogenous short-chain ceramides. Exogenous ceramide analogs were shown to induce apoptosis in several types of tumor cells [65-67]. Encapsulation of exogenous short-chain ceramides (C2-, C6-, C8ceramide) into nanoliposomal formulations for systemic delivery has been studied and results have shown that cell death induction is achieved in multiple syngeneic and xenograft cancer models, and no systemic side effects are observed [68-71]. Besides using shortchain ceramide species, several studies have focused on utilization of novel ceramide analogs which also induce apoptosis in human tumor cells. These analogs and small molecule inhibitors of enzymes such as sphingosine kinase, acid ceramidase or ceramide synthase and mimetics that are implicated in cancer biology will be discussed in detail in further sections of the manuscript.

Ceramide-mediated apoptosis is vital both for cancer cell death and for maintaining homeostasis in healthy cells since Cer is considered to be present in several healthy cells including macrophages and developing embryos [72-73]. Moreover, a recent study undertaken in human head and neck carcinomas has indicated that ceramides with long fatty acid chains such as C18- and C16- exert proapoptotic and prosurvival responses [74]. This explains the significance of ceramides in tumors, and defines the complexity of sphingolipid metabolism and its dysregulation in malignancy.

Sphingosine-1-phosphate, a product of sphingosine kinase, is known to be an anti-apoptotic, tumor-promoting lipid involved in the regulation of survival, proliferation, cell growth, cell migration, inflammation, angiogenesis, and vasculogenesis [75]. S1P binds to G-protein-coupled receptors (GPCRs) (S1P receptors) on the cell surface to elicit cell responses [76]. These S1P receptors have been categorized into a group of five GPCRs identified as S1P1-S1P5 [7, 77]. S1P signalling through these GPCRs has been shown to be atypical in different cancer models [78]. For example, the S1P1 receptor is highly expressed on the surface of malignant lymphoma cells [79] whereas the invasion of glioma cells is shown to be enhanced by the expression of the S1P2 receptor [80]. Levels of S1P are closely related to resistance to apoptotic cell death in cancer; therefore S1P shows antagonizing effects to those of Cer [81]. The cellular ceramide/S1P ratio, also described as the "S1P Rheostat" $[82,83]$, has been proved to be a critical balance determining the survival or death of mammalian cells [84]. Elevated levels of SK/S1P have been detected in various cancer and tumor tissues. Overexpression of SK1 in MCF-7 breast cancer cell line was observed to inhibit apoptosis induced by anticancer agents, including sphingosine and TNF- $\alpha$ [85]. In addition, S1P was shown to activate p38 MAPK and ERK pathways which specifically increase the proliferation of tumor cells and potentiates cell survival [86]. S1P also increases the levels of platelet-derived growth factor (PDGF) and vascular endothelial growth factor (VEGF) which are known to highly affect tumor angiogenesis and cancer cell migration [87-89]. In detail, it was shown that the S1P-induced VEGF mRNA expression was dependent on increased phosphorylation of transcription factors such as phospholipase-C (PLC), Akt, extracellular signalregulated kinases (ERK), AP1, phosphatidylinositol-3 kinase (PI3K) and p38 mitogen-activated protein kinase (MAPK). These results suggest that VEGF receptor gets activated in either autocrine or paracrine fashion following the up-regulation of the expression of VEGF. Therefore, it is postulated that VEGF is likely to have an important role in SP1-mediated cell migration and mitogenesis [88].

SK1 and SK2 were shown to have opposing effects on the regulation of ceramide biosynthesis [90]. Contrary to SK1, SK2 was found to be proapoptotic through calcium-mediated apoptosis. It was thought that cellular location of the S1P product determines its function.

Sphingosine, like ceramide, is a growth inhibitory and proapoptotic sphingolipid, which has been studied in different cell lines including both cancerous and healthy cells [91]. Apoptosis induced by sphingosine was shown to be dependent on cytochromec release from mitochondria and also through the inhibition of PKC [92, 93].

The sphingolipid metabolite, C1P, is formed after phosphorylation of ceramide by the ceramide kinase (CerK), and the reverse reaction is catalyzed by $\mathrm{C} 1 \mathrm{P}$ phosphatase [94]. C1P has opposing regulatory roles when compared to ceramides, and contributes to cancer development by stimulating DNA synthesis and suppressing programmed cell death [95]. PKC was shown to be essential for the proliferative effects of C1P [96]. In a study, apoptosis in macrophages was observed to be inhibited by C1P via suppression of $d e$ novo ceramide synthesis pathway [97]. In macrophages, PI3 kinase, JNK and ERK1/2 pathways were mediated by C1P in order to show pro-survival effects [98]. Additionally to the cell cycle control, C1P was also found to be involved in mammalian inflammatory responses [7].

DhCer is an intermediate in the de novo ceramide synthesis pathway. Several studies have provided evidence that dhCer is an important bioactive sphingolipid. Induction of autophagy following treatment with exogenous dhCer analogs was demonstrated on both gastric and prostate cancer cell lines [99]. DhCer is also assumed to play a role in growth inhibition and hypophosphorylation of $\mathrm{Rb}$ protein [100].

GluCer, which is converted from ceramide by GCS, is an intermediate element in the sphingolipid metabolism [101]. In several studies, it has been shown that GluCer has growth promoting functions, and it is important in chemotherapeutic drug resistance [102, 103]. GluCer was detected to directly upregulate the expression of MDR1 via cSrc and $\beta$-catenin pathways producing chemoresistant cancer subtypes [104]. GluCer levels were found to be elevated in the resistant type of tumors $[105,106]$.

\section{MOLECULES THAT SPECIFICLY INHIBIT BIOLOGI- CALLY ACTIVE SPHINGOLIPIDS}

\subsection{Glucosyl Ceramide Synthase Inhibitors}

1-phenyl-2-palmitoylamino-3-morpholino-1-propanol (PPMP) is a widely used agent in the inhibition of GCS activity in various types of cancer cells Fig. (2). It has been reported that PPMP inhibits GCS in N-(4-hydroxyphenyl) retinamide (4-HPR, fenretinide)sensitive and -resistant CCRF-CEM acute lymphoblastic leukemia cells [107]. PPMP has been also reported to have GCS inhibitory effects on adriamycin-resistant K-562/A02 chronic myeloid leukemia cells and on doxorubicin-resistant MCF-7-AdrR breast cancer cells $[108,109]$. In these cells, GCS inhibition via PPMP treatment 
<smiles>CCCCCCCCCCCCCCCC(=O)N[C@H](CN1CCOCC1)[C@H](O)c1ccccc1</smiles>

PPMP<smiles>CCCCCN1C[C@H](O)[C@@H](O)[C@H](O)[C@H]1CO</smiles>

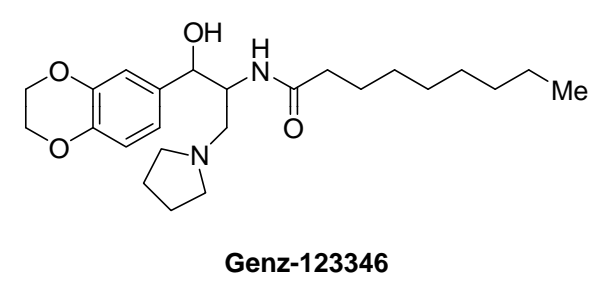

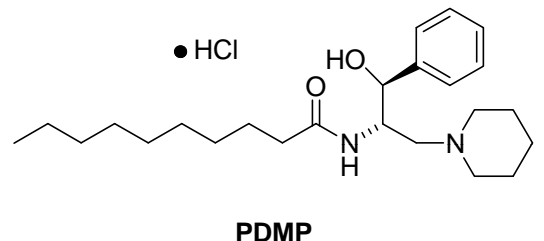<smiles>CCCCN1C[C@H](O)[C@@H](O)[C@H](O)[C@H]1CO</smiles>

NB-DNJ

Fig. (2). Chemical structures of GCS inhibitors.

increases vinblastine uptake, decreases expression levels of MDR1 gene and P-glycoprotein protein, which are important in the development of multidrug resistance. Similarly, these effects of PPMP have been also reported in vinblastine-resistant KB-V0.01 cervix cancer cells [109]. Moreover, in PPMP-treated HL-60 human acute promyelocytic leukemia and U-937 human histiocytic lymphoma cells, PPMP prevents daunorubicine-induced apoptosis, and also PPMP treatment results in an increase in ceramide galactosylation rather than an increase in ceramide levels [110]. In human neuroblastoma, lung, melanoma, colon, breast, and also prostate cancer cells, PPMP has been reported to increase the cytotoxic effects of 4HPR and tamoxifen through p53-independent and caspaseindependent pathways [111]. Furthermore, it has been shown that PPMP treatment in CD4- and several chemokine receptor- bearing osteosarcoma cells results in suppression of glycosphingolipid synthesis and a decrease in HIV infection [112]. In 2007, Chan et al. reported that co-treatment with PPMP increased the cytotoxic effects of C6:ceramide on MDA-MB-435 human breast cancer cells. They also showed that the treatment of MDA-MB-435 cells with PPMP alone results in apoptosis by generating reactive oxygen species [113].

The other commonly used GCS inhibitor in cancer treatment is DL-threo-1-phenyl-2-decanoylamino-3-morpholino-1-propanol

(PDMP) Fig. (2). Like PPMP, PDMP is also used in several types of cancer. Our studies have indicated that PDMP inhibits GCS activity and triggers apoptosis in cancer cells. We have also shown that PDMP inhibits GCS expression, and increases the cytotoxic and apoptotic effects of resveratrol on K-562 human chronic myeloid leukemia, and HL-60 human acute promyelocytic leukemia cells $[114,115]$. In addition, we have demonstrated that PDMP is also effective in sensitizing K-562-IMA imatinib-resistant human chronic myeloid leukemia cells to imatinib [116]. Furthermore, PDMP together with nilotinib have demonstrated significant synergistic apoptotic effects on K-562 cells [117]. We also showed that PDMP increases the cytotoxic effects of dasatinib on K-562 and Meg-01 human chronic myeloid leukemia cells [118]. Moreover, it has been revealed that there are synergistic cytotoxic and apoptotic effects between PDMP and docetaxel on DU-145 and PC-3 human prostate cancer cells [119]. In human U87-MG glioma cells with active p53, PDMP triggered the activation of caspases induced by radiation via accumulating intracellular ceramide [120]. According to a recent study, PDMP treatment of drug-resistant CML T315I mutant cells increases the sensitivity of these cells to imatinib, nilotinib, or GNF-2, an agent used for the inhibition of BCR/ABL in vivo and in vitro, and causes initiation of apoptosis through GSK3 activation [121]. PDMP significantly suppressed VEGF- and FGF-mediated angiogenesis in HUVEC and HAEC, human umbili- cal vein endothelial cells and human aortic endothelial cells, respectively, in vitro, and in nude mice bearing colon cancer [122]. Interestingly, PDMP treatment together with paclitaxel results in abnormal cell cycle progression with hyperploidy rather than ceramide accumulation-triggered apoptosis in Neuro-2a murine neuroblastoma cells [123].

D,L-threo-1-phenyl-2-hexadecanoylamino-3-pyrrolidino-1propanol (PPPP) is the other GCS inhibitor. It has been reported that PPPP is less effective than PDMP in terms of triggering apoptosis in HepG-2 human hepatoma cells [124]. PPPP has been also reported as an effective GCS inhibitor in human neuroblastoma cells [125].

Genz-123346 is another GCS-inhibiting agent used in studies Fig. (2). A study reporting the chemosensitization effects of Genz123346 in different cancer cells, including HCT-15 human colon carcinoma cells, HepG-2 human hepatocellular carcinoma cells, and KB3-1 human cervical cancer cells, showed that Genz-123346 is a substrate for P-gp [126].

Bieberich et al. [127] reported that N-butyldeoxynojirimycin (NB-DNJ) has an inhibitory effect on GCS activitiy Fig. (2). Treatment of neuroblastoma cells resulted in less ceramide accumulation and cell death, suggesting that NB-DNJ is less cytotoxic and apoptotic than PDMP [127]. In addition, treatment of MEB-4 murine melanoma cells with NB-DNJ resulted in inhibition of GCS activitiy, but this treatment did not cause ceramide accumulation or cellular toxicity [128]. Moreover, it was shown that NB-DNJ inhibits GCS activity, while it has no chemosensitivity effect on neuroblastoma cells [129].

OGT2378 is an agent that inhibits GCS function Fig. (2) [130]. In murine models with melanoma, OGT2378 decreased tumor size, and showed no cytotoxic and apoptotic effects on MEB-4 melanoma cells. Additionally, it has been reported that OGT2378 is biologically active, and a well tolerated agent in in vivo system [131].

\subsection{Sphingosine Kinase Inhibitors}

One of the commonly used SK inhibitors is 2-(p-hydroxy anilino)-4-(p-chlorophenyl) thiazole, which is known as SKi Fig. (3). SKi inhibiting both SK-1 and SK-2 function, has cytotoxic and apoptotic effects on several cancer cells [132]. In multidrug resistant breast cancer cells, it decreases cellular proliferation and triggers apoptosis via switching NFKB signaling pathway [133]. SKi is maintained in blood for eight hours in mice after oral administration, and it decreases tumor size [134]. Additionally, according to our studies SKi is significantly effective in undergoing apoptosis 
and chemosensitizing several types of cancer cells, including leukemia and prostate cancer to different anticancer agents. We also found that SKi inhibits SK expression, and increases the cytotoxic and apoptotic effects of resveratrol on K-562 human chronic myeloid leukemia, and HL-60 human acute promyelocytic leukemia cells $[114,115]$. In addition, SKi together with nilotinib have demonstrated significant synergistic apoptotic effects on K-562 cells [117]. According to our studies, SKi increases the cytotoxic effects of dasatinib on K-562 and Meg-01 human chronic myeloid leukemia cells [118]. It has also been reported that there are synergistic cytotoxic and apoptotic effects between PDMP and docetaxel on DU-145 and PC-3 human prostate cancer cells [119].

3-(4-chlorophenyl)-adamantane-1-carboxylic acid (pyridin-4ylmethyl) amide (ABC294640) is a new selective SK-2 inhibitor that suppresses cell proliferation, increases cellular apoptosis, and decreases tumor size in mice bearing kidney carcinoma, hepatoma, or mammary adenocarcinoma Fig. (3) [135, 136]. ABC294640 causes not only apoptosis but also autophagy in different cancer cells, including MDA-MB-231 mammary adenocarcinoma, PC-3 prostate cancer, and also A-498 kidney carcinoma [137].

(2R,3S,4E)-N-methyl-5-(4'-pentylphenyl)-2-aminopent-4-ene1,3-diol (BML258) inhibits selectively SK-1 activity, but not SK-2 Fig. (3). In vitro studies with U937 human histiocytic leukemia and Jurkat acute T-cell leukemia cells, and in vivo studies with leukemic blasts obtained from acute myelogenous leukemia (AML) patients revealed that BML-258 has significant cytotoxic and apoptotic effects on these cells [138].
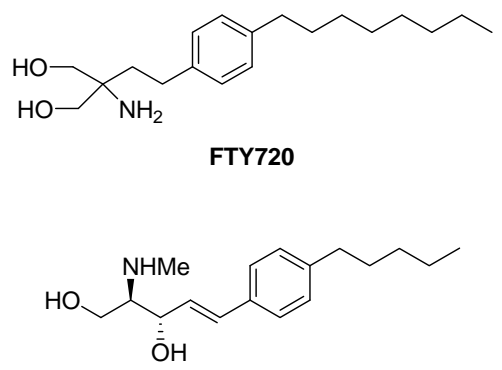

BML258
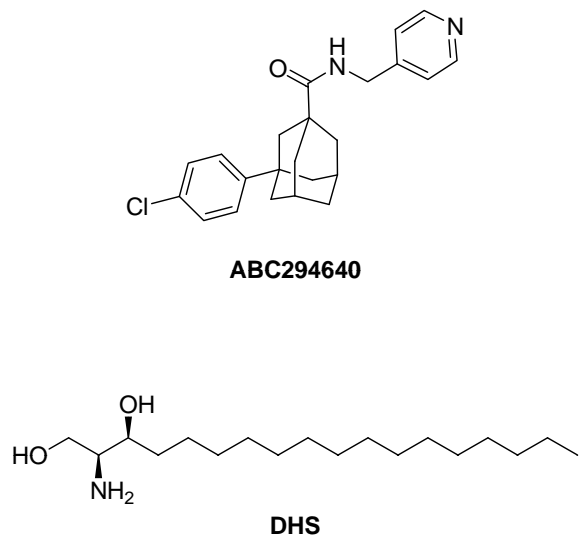<smiles>CCCCCCCCCCCCCC=CC(O)C(CO)N(C)C</smiles><smiles>CCCCCCCCCOc1cc(C)cc(COc2cc(CN3CCCC3CO)cc(CS(=O)(=O)c3ccccc3)c2)c1</smiles>

Fig. (3). Chemical structures of SK inhibitors. 
of the patients having solid tumors with safingol in combination with cisplatin results in hepatic toxicity in a dose-dependent manner, but this effect is reversible [145].

\subsection{Sphingosine-1-Phosphate Receptor Inhibitors}

FTY-720 is an FDA-approved immunosuppresant for the treatment of multiple sclerosis. Besides having SK-1 and SK-2 inhibitory effect, FTY-720 also modulates S1P receptors-except S1PR2 [148]. SK-2 converts FTY-720 to (S)-FTY720 phosphate in vivo, and (S)-FTY720 phosphate can bind S1PR1, 3, 4, and 5, and acts as an antagonist for S1PR1 in terms of functionality [149]. Furthermore, FTY-720 is capable of suppressing metastatic activity in mice with melanoma or breast cancer, and causing a reduction in cellular proliferation, and also triggering apoptosis by preventing the formation of new blood vessels [139, 150].

Kennedy et al. [151] reported that 1-(hydroxymethyl)-3-(3octylphenyl) cyclobutane (VPC03090), an analog of FTY-720, acts as antagonist for S1PR1 and S1PR3. VPC03090-P, converted from VPC03090 through the phosphorylation by SK-2, causes a reduction in tumor growth in mice with mammary cancer, and its oral bioavailability is determined to be 30 hours.

Although the agents mentioned above inhibit S1PR activity, it is known that all cancer cells as well as all cancer patients express S1PRs in a unique and different level. Therefore, in order to gain a successs in cancer therapy via S1PR inhibition, all of the S1PRs must be blocked [152]. For this reason, using anti-S1PRs monoclonal antibodies is a more effective way in targeting all S1PRs and preventing the ligands to bind their receptors. LT1002, known as Sfingomab, is a mouse S1PR monoclonal antibody. In 2006, Visentin et al. firstly characterized sfingomab, and reported that sfingomab treatment results in decreased tumor progression, cellular proliferation, tumor angiogenesis and migration, and prevents ovarian cancer, breast carcinoma, and lung adenocarcinoma cells to escape from apoptotic signals [153]. O’brien et al. [154] developed a humanized S1P antibody, LT1009, known as sonepcizumab. Sonepcizumab treatment of SKOV3 human ovarian carcinoma cells resulted in prevention of binding of S1P to S1PRs, and by this way, the prevention of S1P-triggered release of IL-8 cytokine which is important in angiogenesis and metastasis [154]. Phase I clinical trials demonstrated that sonepcizumab treatment of patients with solid tumors such as colorectal, breast, ovarian, renal, prostate, and head-and-neck cancer resulted in stable disease, and no disease progression was observed for approximately 8-12 months in most of the patients. Additionally, sonepcizumab treatment was welltolerated in cancer patients, and it was demonstrated to be important in trafficking of lymphocytes. S1P activity was found to increase lymphocyte number, while sonepcizumab treatment was shown to decrease it $[152,155]$.

\subsection{Ceramidase Inhibitors}

Neutral and acid ceramidase activities were found to be increased in tumors as compared to normal cells [156-158]. Therefore, inhibition of ceramidases is an alternative strategy to induce ceramide accumulation and apoptotis in cancer cells.

Currently, different ceramidase inhibitors are being developed as anticancer drugs, either alone or in combination with other therapies Fig. (4). An alkaline ceramidase specific inhibitor called $1 S$,2R-D-erythro-2-( $N$-myristoylamino)-1-phenyl-1-propanol (Derythro-MAPP) was shown to cause growth suppression and cell cycle arrest in HL-60 human promyelocytic leukemia cells [159]. On the other hand, D-MAPP also fuctions as a moderate but selective inhibitor of acid ceramidase in human melanoma and HaCat keratinocytes in which D-MAPP induces apoptosis by increasing endogeneous ceramide levels [160]. According to another report, D-MAPP in combination with DL-PDMP (a specific inhibitor of glucosylceramide synthase) and imipramine (an amphiphilic amine responsible for lipid turnover in biological membranes) increased the apoptotic effect of ionizing radiation in Jurkat cells [161] and sensitized radioresistant SQ20B squamous carcinoma cells to $\chi$-rays [162]. Inhibiting the acid ceramidase is an another potential strategy for cancer therapy since it is upregulated in several cancers and confers resistance to chemo- and radiotherapy [163, 164]. $1 R, 2 R$-derythro-2- $N$-myristoylamino-1-nitrophenyl-propan-1,2-diol (B13), an acid ceramidase inhibitor, increased ceramide levels and induced apoptosis in SW-403 human metastatic colorectal cancer cells but not in normal cells. Morever, B13, also called D-NMAPPD, prevented tumor growth in nude mice in which metastatic colon cancer was established by using SW-403 and Lovo human colon cancer cells [165]. Apoptotic effects of B13 were shown on cultured $\mathrm{LNCaP}$ and PC-3 prostate cancer cells. In addition, treatment of androgen-insensitive prostate cancer xenografts with B13 showed that B13 increased sensitivity of tumors to radiation and caused a significant reduction in tumor size [166]. Acid ceramidase inhibition has been also triggered by N-oleoylethanolamine (NOE) which is responsible for the initiation of antiproliferative effects in a variety of cancer cells [167]. Spinedi et al. [168] showed that exposure of CHP-100 neuroepithelioma cells to increasing concentrations of NOE induced apoptosis of these cells by inhibiting acid ceramidase and glucosylation of naturally occurring ceramides. Tavarini et al. [169] treated SH-SY5Y neuroblastoma cells and showed the effect of NOE on cell viability. In another report, C6 glioma cells were pretreated with NOE and NOE increased the apoptotic effects of<smiles>CC(C=CC(C)(C)C)C(C)(C)C(=O)NCCO</smiles>

NOE

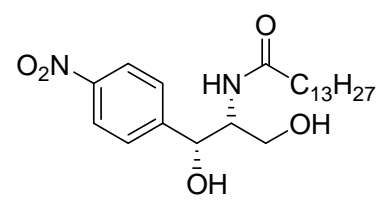

B13<smiles>CC[C@H](NC([14CH3])=O)[C@@H](O)c1ccccc1</smiles>

D-MAPP

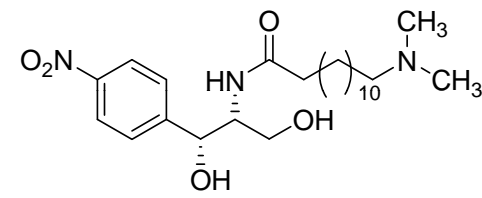

LCL464<smiles>[14CH3]CN[C@@H](CO)[C@H](O)c1ccc([N+](=O)[O-])cc1</smiles>

LCL204<smiles>OCC(CO)[C@H](O)c1ccccc1</smiles>

LCL385

Fig. (4). Chemical structures of ceramidase inhibitors and their analogs. 
cisplatin. Furthermore, NOE made cisplatin-resistant cells sensitive to cisplatin [170]. NOE-mediated pharmacological inhibition of acid ceramidase increased ceramide generation in hepatoma cells such as HepG2, Hep-3B, SK-Hep and Hepa1c1c7 and, sensitized them to daunorubicin-induced cell death. NOE also reduced tumor growth in vivo in a murine model of hepatocellular carcinoma [171]. NOE was also found to be effective against sarcoma and neuroectodermal tumor cell lines and treatment with NOE sensitized these cells to fenretinide-induced apoptosis [45]. Although NOE has been used in various basic studies, it is excluded from any therapeutic use due to its low potency and pure selectivity [172]. (2R,3Z)-N-(1-hydroxyoctadec-3-en-2-yl) pivalamide (DM102), an acid ceramidase inhibitor, was shown to decrease cell viability in A549 human lung adenocarcinoma cells in dose-dependent manner and cause cell cycle arrest at G1 [173]. In a recent study, DM102 showed synergistic effects when applied together with fenretinide [4-HPR] to PC-3 and DU 145 hormone-refractory human prostate cancer cells. This combination increased caspase activity, ceramide and ROS levels [174]. Flowers et al. [175] examined apoptotic effects of C6-ceramide, DM102 and their combinations in human breast cancer cells and found that C6-ceramide-DM102 combination triggered apoptosis via activation of capsase $3 / 7$, mitochondrial membrane depolarization and ROS production.

Several ceramidase inhibitor analogs have been developed recently in order to improve the activity of ceramidase inhibitors described in this study. LCL204, a lysomotropic analog of B13, was designed and synthesized by Holman et al. [158]. LCL204 increased ceramide and decreased sphingosine levels in DU-145 prostate cancer cells, and thereby LCL204 might function as a novel treatment option for prostate cancer [158]. In addition, this compound sensitized head and neck squamous (HNSCC) cells to Fas-induced apoptosis both in vitro and in a xenograft model. Therefore, Fas ligand and LCL204 combination therapy may be a new approach for advanced-stage head and neck cancer [157]. LCL385, another analog of B13, was shown to increase the sensitivity of PPC- 1 prostate cancer cells to radiation and significantly decrease tumor size in tumor xenografts generated in nude mice

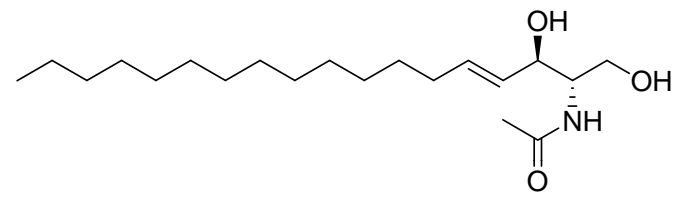

C2-Ceramide

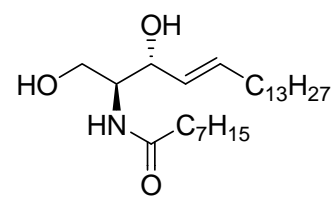

C8-Ceramide

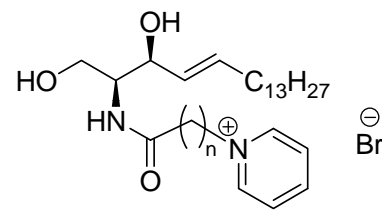

LC-124
[176]. Bai et al. [177] designed a second generation B-13 analog, LCL 464, and investigated its apoptotic effects on MCF-7 cells. Compared with LCL204, it showed greater inhibition of acid ceramidase in living cells. Lee et al. [178] synthesized and investigated the cytotoxic effects of twenty-one B13 sulfonamides on both colon cancer HT-29 and A-549 lung cancer cells. Some B13 sulfonamides showed more toxicity on both cells when compared with B13. In another study, novel NOE analogs were synthesized and their acid ceramidase inhibitory potentials were evaluated on cultured cells. Some of these synthesized compounds showed inhibitory effects and might be considered as novel acid ceramidase inhibitors [172].

\subsection{Synthetic Ceramide Analogs}

There is a strong relationship between ceramides and apoptosis in cancer cells [179]. Therefore, increasing the concentration of intracellular ceramide can be an appropriate strategy for effective treatment of cancer. One of the possible strategies includes the treatment of cancer cells with exogenous synthetic ceramide analogs Fig. (5) or mimetics that were shown to mimic endogeneous ceramide in terms of inducing apoptosis in a variety of cancer lines.

Natural ceramide is unable to pass through the cell membrane, so it can not be used directly for cancer therapy [180]. Therefore, numerous ceramide analogs with unique properties have been developed. They include cell-permeable, short chain ceramides, analogs with additional double bonds, analogs containing disulfide linkages, conjugates of ceramides and dihydroceramides [181, 182]. Some of them have improved solubility, easier cellular uptake and the ability to be localized in different compartments such as mitochondria and lysosomes in the cell. Some are responsible for inducing mitochondrial apoptosis, consuming cellular glutathione and causing cytotoxicity in malignant cells [13]. In almost all studies, compared to long-chain (C18-C24) ceramides, short- and mediumchain ceramide analogs, C2 (N-acetyl-sphingosine), C6 (Nhexanoyl-sphingosine), or C8 (N-octanoyl-sphingosine) ceramides have been more commonly used due to their solubility in cell growth medium and easy enterance into the cell [183].

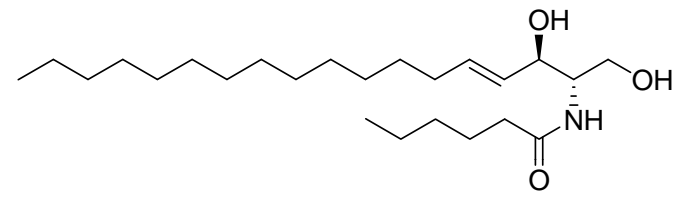

c6-Ceramide

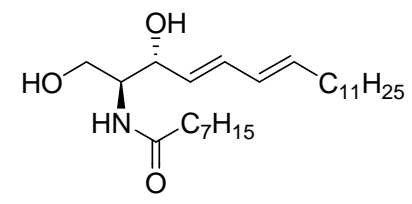

4,6-diene-Cer<smiles>CCCCCCCCCCCCCCCC(=O)NC(CO)CO</smiles>

C16-Serinol

Fig. (5). Structures of current ceramide analogs. 
C2-, C6-, and C8-ceramide analogs have been shown to induce apoptosis in human CEM-C7H2 acute lymphoblastic T-cell leukemia cells [184]. Kuroki et al. [185] investigated the effects of C2-ceramide on the growth of TNF-alpha-resistant B lymphoma Raji cells together with TNF-alpha-sensitive myeloid leukemia cells (HL-60 and U-937). C2-ceramide caused apoptotic cell death in HL-60 and U-937 cells, but did not induce apoptosis in Raji cells. C2-ceramide mediated growth inhibition in Raji cells was found to be related with cell cycle arrest in G0/G1 [185]. In some studies, the relationship between ceramide analogs and caspases were determined. For instance, treatment of Jurkat cells with C2-ceramide activated caspase- 3 and -7 that subsequently cleaved poly (ADPribose) polymerase (PARP) [186]. In another report, time- and dose- dependent cell death induced in HL-60 cells treated with C2ceramide and its homologs were due to DNA fragmentation, proteolytic cleavage of pro-caspase-3 and the cleavage of PARP [187]. Selzner et al. [165] displayed the apoptotic effects of C2- and C6ceramide in SW-403 human colon cancer cells. Fillet et al. [188] clearly demostrated that C2- and C6- ceramides activated NF- $\mathrm{BB}$, induced caspase-3 activity, PARP cleavage and cyctochrome c release in both human colon carcinoma cells and ovarian carcinoma cells whereas C16-ceramide did not enter into these cells.

The cell death related effects of ceramide analogs have been shown to be against a variety of cancer cell lines. Recently, significant attention has been paid to the potential usage of ceramide analogs as adjuvants with conventional chemotherapeutic agents. Charles et al. [189] showed the induction of apoptosis more effectively in MDA-MB-468 human breast cancer cells that were treated with taxol C6-ceramide combination. C6-ceramide increased the apoptotic effects of doxorubicin in multiple cell lines including MCF-7 via activation of AMP-activated protein kinase (AMPK), mTOR inhibition and Bcl-2 downregulation [190]. Our group is also interested in the apoptotic roles of ceramide in several different cancer types. For instance, Gencer et al. [118] examined the therapeutic potentials of C8-ceramide in combination with dasatinib in K562 and Meg-01 chronic myeloid leukemia cells and showed that exogenous C8-ceramide application increased the apoptotic effects of dasatinib. In one of our studies we found that the sensitivity of human chronic myeloid leukemia cells increased to nilotinib via coadministration of C8-ceramide [117]. Combination of C:8 ceramide increased the antiproliferative and apoptotic effects of resveratrol on chronic myeloid leukemia [114] and acute myeloid leukemia [115] cells while combination of docetaxel with C8:ceramide showed significant synergistic apoptosis on prostate cancer cell lines [119]. In a recent report, Zhu et al. [191] investigated the synergistic effects of histone deacetylase inhibitor, TSA, and C6ceramide both in vitro and in vivo pancreatic and ovarian cancer models. TSA in combination with C6-ceramide induced apoptosis by inhibiting AKT and hyperacetylating $\alpha$-tubulin.

Several structural ceramide analogs as well as short-chain ceramides (C2, C6 and C8) have been developed and shown to induce apoptosis in a variety of cancer lines. For instance, Karasawas et al. [192] showed the apoptotic potential of C8-ceramide stereoisomers, N-octanoyl-DL-erythrodihydrosphingosine (DL-e-DHC $\mathbf{8}_{\mathbf{8}}$-Cer) and N-octyl-D-erythro-sphingosine (D-e-C $\mathbf{C}_{\mathbf{8}}$-Ceramine), which have an amine instead of an amide bond, on U-937 leukemia cells. FS-5, another structural analog, induced apoptotic cell death in Molt-4 leukemic cells [193]. Ceramide analogs, C16-serinol and C18serinol, were shown to trigger apoptotic signaling pathways in human neuroblastoma, glioma, medulloblastoma, and adenocarcinoma cells [67, 66]. The properties of these ceramide mimetics such as tumor specificity, increased water solubility, rapid uptake and slow release from the cells make them potential candidates for cancer therapy [66]. Crawford et al. [194] found that novel ceramide analogs, 5R-OH-3E-C8-ceramide, adamantyl-ceramide and benzene-C4-ceramide, showed increased cytotoxicity against drug-resistant breast tumor cells, SKBr3 and MCF-7/Adr, compared with normal breast epithelial cells. 4,6-diene-Cer, a novel ceramide analog, was effective in inducing apoptosis in MCF-7 breast cancer cells by causing the release of cytochrome $\mathrm{c}$ and a decrease in the mitochondrial membrane potential [195]. The cationic C8ceramide analog has been shown to inhibit clonogenic survival and induce apoptosis in endocrine-resistant MDA-MB-231 and chemoresistant MCF-7 TN-R breast cancer cells [196]. Ha et al. [197] synthesized several ceramide analogs and showed that these analogs exhibited potent antileukemic activities against human leukemia HL-60 cells by causing DNA fragmentation. Novel ceramide analogs, AD2646 and AD2687, induced cell death in Jurkat leukemic cells both by caspase -dependent and - independent pathways [198]. Dagan et al. [199] found that three different ceramide analogs, AD2646, AD2672 and AD2665, had cytotoxic and apoptotic effects on HL-60 leukemic cells. To clarify the relationship between ceramide-induced cell death and mitochondria, positively charged ceramides have been developed and shown to increase mitochondrial inner membrane permeability and cause the release of cytochrome c by activating specific ion transporters like $\mathrm{H}^{+}$ transporter [200, 201]. Senkal et al. [202] determined the growthinhibitory function of a highly soluble cationic pyridinium ceramide, L-threo-C6-pyridinium-ceramide-bromide (LCL-124), alone and in combination with gemcitabine in HNSCC cells and HNSCC tumors in SCID mice. Combination therapy resulted in increased tumor suppression in mice via inhibition of telomerase activity and caused a decrease in telomere length. In addition, such novel pyridinium ceramides have been shown to cause cell cycle arrest in G0/G1 together with inhibiton of telomerase activity [203]. LCL29, $D$-erythro isomer of LCL-24, was applied to mouse SCCVII squamous cell carcinoma tumors in combination with PhotofrinPhotodynamic therapy (PDT). Although LCL-29 had no effect on tumor growth alone, tumor growth retarded by PDT was enhanced by LCL-29 [204, 205]. Dindo et al. [206] characterized the effects of the newly synthesized cationic long chain-ceramide, LCL-30, in SW403 cells and showed that LCL-30 specifically accumulated in the mitochondria and induced apoptosis by the mitochondrial pathway. LCL-30 was firstly tested in an in vivo model of metastatic colorectal cancer by Dahm et al. [207]. LCL-30 caused a reduction in the proliferative activity and the growth of the established tumor in BALB/c mice. Positive charge of such ceramide analogs is responsible for their targeting and accumulation especially into mitochondria (sometimes into nucleus) of cancer cells which have been shown to acquire a higher negative membrane potential compared with normal cells [208].

Cell permeable ceramide analogs may show reduced efficieny due to their hydrophibicity and precipitation when applied in aqueous solutions [183]. To overcome such problems, it is important to develop novel delivery methods to increase the intracellular ceramide accumulation. Stover et al. [209] described the liposomal delivery of C6-ceramide into MDA-MB-231 breast cancer cells and results were compared with nonliposomal administration of ceramide. These targeted C6-ceramide can regulate Akt phosphorylation and activate caspase 3/7 more effectively. Moreover, pegylated liposomal formulation of C6-ceramide was delivered systemically into a syngeneic BALB/c mouse model of breast adenocarcinoma. The results indicated that liposomal C6-ceramide treatment caused a dose-dependent inhibition of tumor growth as compared with untreated controls [70]. In another study, polymeric nanoparticlecoated C6-ceramide was introduced into a multidrug-resistant SKOV-3 ovarian cancer cells together with paclitaxel to induce apoptotic cell death and overcome multidrug resistance [210].

\subsection{Ceramide Kinase Inhibitors}

Ceramide-1-phosphate (C1P) is a significant signaling molecule that activates cell survival and proliferation while blocking apoptosis, thereby $\mathrm{C} 1 \mathrm{P}$ and ceramide are antagonistic molecules that can be converted into each other by kinase and phosphatase enzymes $[211,212]$. 


\section{Table 1. Overview of GCS Inhibitors}

\begin{tabular}{|c|c|c|c|}
\hline \multirow{2}{*}{ Compound } & \multicolumn{2}{|c|}{ Preclinical Studies } & \multirow[t]{2}{*}{ Clinical Phase Studies } \\
\hline & In vitro Studies & Animal Studies & \\
\hline PPMP & $\begin{array}{l}\text { Acute lymphoblastic leukemia, chronic } \\
\text { myeloid leukemia, acute promyelocytic } \\
\text { leukemia, breast cancer, cervix cancer, } \\
\text { histiocytic lymphoma, neuroblastoma, } \\
\text { lung cancer, melanoma, colon cancer, } \\
\text { prostate cancer, osteosarcoma }\end{array}$ & & \\
\hline PDMP & $\begin{array}{l}\text { Chronic myeloid leukemia, acute pro- } \\
\text { myelocytic leukemia, breast cancer, } \\
\text { neuroblastoma, glioma, colon cancer, } \\
\text { prostate cancer }\end{array}$ & Colon cancer, chronic myeloid leukemia & \\
\hline PPPP & Hepatoma, neuroblastoma & & \\
\hline Genz-123346 & $\begin{array}{l}\text { Colon cancer, hepatocellular carcinoma, } \\
\text { cervical cancer }\end{array}$ & & \\
\hline NB-DNJ & Melanoma, neuroblastoma & & \\
\hline OGT2378 & Melanoma & Melanoma & \\
\hline
\end{tabular}

Table 2. Overview of SK Inhibitors and S1PR Inhibitors

\begin{tabular}{|c|c|c|c|}
\hline \multirow{2}{*}{ Compound } & \multicolumn{2}{|c|}{ Preclinical Studies } & \multirow[t]{2}{*}{ Clinical Phase Studies } \\
\hline & In vitro Studies & Animal Studies & \\
\hline SKi & $\begin{array}{l}\text { Breast cancer, prostate cancer, chronic } \\
\text { myeloid leukemia, acute promyelocytic } \\
\text { leukemia }\end{array}$ & & \\
\hline АВC294640 & $\begin{array}{c}\text { Kidney carcinoma, hepatoma, mammary } \\
\text { adenocarcinoma, prostate cancer }\end{array}$ & $\begin{array}{c}\text { Kidney carcinoma, hepatoma, breast } \\
\text { cancer }\end{array}$ & \\
\hline BML258 & $\begin{array}{l}\text { Histiocytic leukemia, acute T-cell leuke- } \\
\text { mia, acute myelogenous leukemia }\end{array}$ & Acute myelogenous leukemia & \\
\hline FTY720 & $\begin{array}{l}\text { Breast cancer, myeloma, leukemia, } \\
\text { melanoma }\end{array}$ & Melanoma, breast cancer, leukemia & \\
\hline DMS & Colon cancer & & \\
\hline PF543 & Head and neck cancer & & \\
\hline DHS & $\begin{array}{l}\text { Solid tumors including adrenal cortical } \\
\text { cancer, liver cancer, lung cancer }\end{array}$ & Solid tumors & Solid tumors \\
\hline VPC03090 & Mammary cancer & Mammary cancer & \\
\hline LT1002 & $\begin{array}{c}\text { Breast cancer, ovarian cancer, lung } \\
\text { adenocarcinoma }\end{array}$ & $\begin{array}{l}\text { Breast cancer, ovarian cancer, lung } \\
\text { adenocarcinoma }\end{array}$ & \\
\hline LT1009 & Ovarian cancer & Breast cancer, ovarian cancer & $\begin{array}{c}\text { Colorectal cancer, breast cancer, ovarian } \\
\text { cancer, renal cancer, prostate cancer, } \\
\text { head and neck cancer }\end{array}$ \\
\hline
\end{tabular}

Table 3. Common Analogs and Inhibitors of Ceramide Metabolism

\begin{tabular}{|c|c|c|}
\hline Compound & Mechanism & Preclinical Studies \\
\hline D-MAPP & Alkaline ceramidase inhibitor & $\begin{array}{l}\text { In vitro studies: melanoma, promyelocytic leukemia, } \\
\text { squamous cell carcinoma cells } \\
\text { Animal studies: not studied }\end{array}$ \\
\hline B13 & Acid ceramidase inhibitor & $\begin{array}{l}\text { In vitro studies: colorecteral, prostate cancer cells } \\
\text { Animal studies: mice xenografts of colon and prostate } \\
\text { cancer }\end{array}$ \\
\hline NOE & Acid ceramidase inhibitor & $\begin{array}{l}\text { In vitro studies: Hepatoma, glioma, sarcoma cells } \\
\text { Animal studies: murine model of hepotacellular carci- } \\
\text { noma }\end{array}$ \\
\hline Short-chain ceramides (C2-C6-, C8-ceramide) & Ceramide analog & $\begin{array}{l}\text { In vitro studies: Acute lymphoblastic T-cell leukemia, } \\
\text { breast, chronic myeloid leukemia, ovarian cancer cells } \\
\text { Animal studies: mice xenografts of pancreatic and } \\
\text { overian cancer, mouse model of breast cancer }\end{array}$ \\
\hline
\end{tabular}


(Table 3) contd.....

\begin{tabular}{|c|c|c|}
\hline Compound & Mechanism & Preclinical Studies \\
\hline C16-serinol and C18-serinol & Ceramide analog & $\begin{array}{l}\text { In vitro studies: neuroblastoma, glioma, adenocarci- } \\
\text { noma cells } \\
\text { Animal studies: not studied }\end{array}$ \\
\hline Adamantyl-ceramide & Ceramide analog & $\begin{array}{l}\text { In vitro studies: Breast cancer cells } \\
\text { Animal studies: not studied }\end{array}$ \\
\hline 4,6-diene-Cer & Ceramide analog & $\begin{array}{l}\text { In vitro studies: Breast cancer cells } \\
\text { Animal studies: not studied }\end{array}$ \\
\hline Cationic pyridiniumceramide & Mitochondrial targeting & $\begin{array}{l}\text { In vitro studies: HNSCC, squamous cancer, colon } \\
\text { cancer cells } \\
\text { Animal studies: HNSCC tumor model and colon cancer } \\
\text { model in mice }\end{array}$ \\
\hline K1 & Ceramide kinase inhibitor & $\begin{array}{l}\text { In vitro studies: basophilic leukemia cells } \\
\text { Animal studies: not studied }\end{array}$ \\
\hline NVP-231 & Ceramide kinase inhibitor & In vitro and animal studies: Not studied \\
\hline
\end{tabular}

* Clinical phase studies have not been performed yet for these inhibitors and anologs.<smiles>O=C(Nc1nc2ccc(NC(=O)C34CC5CC(CC(C5)C3)C4)cc2s1)c1ccccc1</smiles>

NVP-231<smiles>COc1ccc(C(=O)Nc2nc3ccc(NC(=O)C45CC6CC(CC(C6)C4)C5)cc3s2)cc1OC</smiles>

NVP-995
Fig. (6). Stuctures of novel ceramide kinase inhibitors.

Based on the relationship between cancer and ceramide kinase (CerK), inhibition of CerK may be a promising strategy in cancer therapies, especially to enhance the efficacy of anti-cancer therapies such as drugs, radiation and immunotherapy [213].

Specific CerK inhibitors Fig. (6) have been characterized in only a few studies with different assay procedures and they are just in their first decade [214, 215]. K1 was found to function as a noncompetitive CerK inhibitor and caused a partial inhibition of CerK and $\mathrm{C} 1 \mathrm{P}$ production without any effect on cell growth in RBL-2H3 cells [216]. Munagala et al. [214] identified and characterized several potential CerK inhibitors using a chemiluminescence based assay. The first potent competitive CerK inhibitor was identified by Graf et al. [217] and it was called NVP-231, adamantane-1carboxylic acid [2-benzoylamino-benzothiazol-6-yl] amide. NVP231 was found to be highly specific for CerK and to function efficiently both in vitro and in cell-based assays. The combination of NVP-231 with tamoxifen increased the ceramide levels in a cellular system [213, 215]. Another CerK inhibitor, NVP-995, was found to be less potent and used as a control in cellular assays [215].

\section{CONCLUSION AND FUTURE PERSPECTIVES}

Sphingolipids are vital constituents of the cells, and play significant roles in the regulation of various cellular processes, most importantly in cell proliferation, cell differentiation and programmed cell death. Therefore, dysregulation of the sphingolipid metabolism leads to oncogenesis, tumor progression and drug resistance. Targeting the elements of sphingolipid metabolism appears to be important for the development of novel anti-cancer therapeutics or to increase the effectiveness of the current treatment strategies. Different approaches mainly aim to up-regulate the levels of apoptotic sphingolipids such as ceramides and sphingosine, while the proliferative ones including $\mathrm{C} 1 \mathrm{P}, \mathrm{S} 1 \mathrm{P}$ and GluCer are downregulated. Delivery of the cytotoxic sphingolipids like short chain ceramide analogs to the tumor cells can also be considered in order to establish chemotherapeutic intervention. In other words, manipulation of sphingolipid metabolism is considered to be a good approach for development of novel therapies. It is believed that a combination therapy with conventional cytotoxic drugs while increasing the levels of pro-apoptotic ceramide can be more beneficial [116-119]. However, because apoptotic sphingolipids may cause cytotoxicity in non-cancerous cells, delivering cytotoxic species specifically to the malignant cells remains as an important issue that should be concentrated on. For this reason, research conducted in the cell culture should be carried further, and more in vivo experiments are needed to be conducted. By this way, the actual potential of sphingolipid metabolism as an anti-cancer treatment regimen will be discovered. In the light of the growing literature in this area, it is suffice to say that sphingolipid metabolism holds a great promise for the future treatments of multiple cancer types.

\section{CONFLICT OF INTEREST}

The authors do not have any kind of conflict of interest affecting the compilation of the current knowledge in this area for writing this review.

\section{ACKNOWLEDGEMENTS}

We thank Dr Ali Çağır from İzmir Institute of Technology, Department of Chemistry for his valuable contribution to drawing the chemical structures in CHEMDRAW programme and Academic Writing Center of İzmir Institute of Technology for editing the manuscript.

\section{REFERENCES}

[1] Futerman, A.H.; Hannun, Y.A. The complex life of simple sphingolipids. EMBO Rep., 2004, 5(8), 777-782.

[2] Hannun, Y.A. Functions of ceramide in coordinating cellular responses to stress. Science, 1996, 274(5294), 1855-1859. 
[3] Hannun, Y.A.; Obeid, L.M.; Wolff, R.A. The novel second messenger ceramide: identification, mechanism of action, and cellular activity. Adv. Lipid Res., 1993, 25, 43-64.

[4] Ruvolo, P.P. Intracellular signal transduction pathways activated by ceramide and its metabolites. Pharmacol. Res., 2003, 47(5), 383-392.

[5] Jung, E.M.; Griner, R.D.; Mann-Blakeney, R.; Bollag, W.B. A potential role for ceramide in the regulation of mouse epidermal keratinocyte proliferation and differentiation. J. Invest. Dermatol., 1998, 110(4), 318-323.

[6] Haimovitz-Friedman, A.; Kolesnick, R.N.; Fuks, Z. Ceramide signaling in apoptosis. Br. Med. Bull., 1997, 53(3), 539-553.

[7] Chalfant, C.E.; Spiegel, S. Sphingosine 1-phosphate and ceramide 1phosphate: expanding roles in cell signaling. J. Cell Sci., 2005, 118(Pt 20), 4605-4612.

[8] Lee, M.J.; Thangada, S.; Claffey, K.P.; Ancellin, N.; Liu, C.H.; Kluk, M.; Volpi, M.; Sha'afi, R.I.; Hla, T. Vascular endothelial cell adherens junction assembly and morphogenesis induced by sphingosine-1-phosphate. Cell, 1999, 99(3), 301-312.

[9] Ruvolo, P.P.; Gao, F.; Blalock, W.L.; Deng, X.; May, W.S. Ceramide regulates protein synthesis by a novel mechanism involving the cellular PKR activator RAX. J. Biol. Chem., 2001, 276(15), 11754-11758.

[10] Lee, Y.J.; Amoscato, A.A. TRAIL and ceramide. Vitam. Horm., 2004, 67, 229-255.

[11] Andrieu-Abadie, N.; Gouaze, V.; Salvayre, R.; Levade, T. Ceramide in apoptosis signaling: relationship with oxidative stress. Free Radic. Biol. Med., 2001, 31(6), 717-728.

[12] Yang, G.; Badeanlou, L.; Bielawski, J.; Roberts, A.J.; Hannun, Y.A.; Samad, F. Central role of ceramide biosynthesis in body weight regulation, energy metabolism, and the metabolic syndrome. Am. J. Physiol. Endocrinol. Metab., 2009, 297(1), E211-E224.

[13] Oskouian, B.; Saba, J.D. Cancer treatment strategies targeting sphingolipid metabolism. Adv. Exp. Med. Biol., 2010, 688, 185-205.

[14] Hannun, Y.A.; Obeid, L.M. Principles of bioactive lipid signalling: lessons from sphingolipids. Nat. Rev. Mol. Cell Biol., 2008, 9(2), 139-150.

[15] Zheng, W.; Kollmeyer, J.; Symolon, H.; Momin, A.; Munter, E.; Wang, E.; Kelly, S.; Allegood, J.C.; Liu, Y.; Peng, Q.; Ramaraju, H.; Sullards, M.C.; Cabot, M.; Merrill, A.H. Ceramides and other bioactive sphingolipid backbones in health and disease: lipidomic analysis, metabolism and roles in membrane structure, dynamics, signaling and autophagy. Biochim. Biophys. Acta., 2006, 1758(12), 1864-1884.

[16] Furuya, H.; Shimizu, Y.; Kawamori, T. Sphingolipids in cancer. Cancer Metastasis Rev., 2011, 30(3-4), 567-576.

[17] Kolesnick, R.N.; Haimovitz-Friedman, A.; Fuks, Z. The sphingomyelin signal transduction pathway mediates apoptosis for tumor necrosis factor, Fas, and ionizing radiation. Biochem. Cell. Biol., 1994, 72(11-12), 471-474.

[18] Goldkorn, T; Balaban, N.; Shannon, M. Chea, V; Matsukuma, K; Gilchrist, D.; Wang, H.; Chan, C. H2O2 acts on cellular membranes to generate ceramide signaling and initiate apoptosis in tracheobronchial epithelial cells. J. Cell Sci., 1998, 111(Pt 21), 3209-3220.

[19] Bose, R.; Verheij, M.; Haimovitz-Friedman, A.; Scotto, K.; Fuks, Z.; Kolesnick, R. Ceramide synthase mediates daunorubicin-induced apoptosis: an alternative mechanism for generating death signals. Cell, 1995, 82(3), $405-414$

[20] Michel, C.; van Echten-Deckert, G. Conversion of dihydroceramide to ceramide occurs at the cytosolic face of the endoplasmic reticulum. FEBS Lett., 1997, 416(2), 153-155.

[21] Hannun, Y.A.; Obeid, L.M. The ceramide-centric universe of lipid-mediated cell regulation: stress encounters of the lipid kind. J. Biol. Chem., 2002, 277(29), 25847-25850.

[22] Linn, S.C.; Kim, H.S.; Keane, E.M.; Andras, L.M.; Wang, E.; Merrill, A.H. Regulation of de novo sphingolipid biosynthesis and the toxic consequences of its disruption. Biochem. Soc. Trans., 2001, 29(6), 831-835.

[23] Nagiec, M.M.; Lester, R.L.; Dickson, R.C. Sphingolipid synthesis: identification and characterization of mammalian cDNAs encoding the Lcb2 subunit of serine palmitoyltransferase. Gene, 1996, 177(1-2), 237-241.

[24] Merrill, A.H.Jr.; Wang, E.; Mullins, R.E. Kinetics of long-chain (sphingoid) base biosynthesis in intact LM cells: effects of varying the extracellular concentrations of serine and fatty acid precursors of this pathway. Biochemistry, 1988, 27(1), 340-345.

[25] Mandon, E.C.; Ehses, I.; Rother, J.; van Echten, G.; Sandhoff, K. Subcellular localization and membrane topology of serine palmitoyltransferase, 3dehydrosphinganine reductase, and sphinganine $\mathrm{N}$-acyltransferase in mouse liver. J. Biol. Chem., 1992, 267(16), 11144-11148.

[26] Pewzner-Jung, Y.; Ben-Dor, S.; Futerman, A.H. When do Lasses (longevity assurance genes) become CerS (ceramide synthases)?: insights into the regulation of ceramide synthesis. J. Biol. Chem., 2006, 281(35), 25001-25005.

[27] Geeraert, L.; Mannaerts, G.P.; van Veldhoven, P.P. Conversion of dihydroceramide into ceramide: involvement of a desaturase. Biochem. J., 1997, 327(Pt 1), 125-132.

[28] Okazaki, T.; Bell, R.; Hannun, Y. Sphingomyelin turnover induced by vitamin D3 in HL-60 cells. J. Biol. Chem., 1989, 264(32), 19076-19080.

[29] Xu, R.; Sun, W.; Jin, J.; Obeid, L.M.; Mao, C. Role of alkaline ceramidases in the generation of sphingosine and its phosphate in erythrocytes. FASEB J., 2010, 24(7), 2507-2515.

[30] Clarke, C.J.; Snook, C.F.; Tani, M.; Matmati, N.; Marchesini, N.; Hannun, Y.A. The extended family of neutral sphingomyelinases. Biochemistry, 2006,
45(38), 11247-11256.

Liu, B.; Obeid, L.; Hannun, Y. Sphingomyelinases in cell regulation. Semin. Cell Dev. Biol., 1998, 8(3), 311-322

[32] Marchesini, N.; Hannun, Y.A. Acid and neutral sphingomyelinases: roles and mechanisms of regulation. Biochem. Cell Biol., 2004, 82(1), 27-44.

[33] Gomez-Munoz, A.; Kong, J.Y.; Salh, B.; Steinbrecher, U.P. Ceramide-1phosphate blocks apoptosis through inhibition of acid SMase in macrophages. J. Lipid Res., 2004, 45(1), 99-105.

[34] Kolesnick, R.; Golde, D.W. The sphingomyelin pathway in tumor necrosis factor and interleukin-1 signaling. Cell, 1994, 77(3), 325-328.

[35] Tafesse, F.G.; Ternes, P.; Holthuis, J.C. The multigenic sphingomyelin synthase family. J. Biol. Chem., 2006, 281(40), 29421-29425.

[36] Kudo, N.; Kumagai, K.; Tomishige, N.; Yamaji, T.; Wakatsuki, S.; Nishijima, M.; Hanada, K.; Kato, R. Structural basis for specific lipid recognition by CERT responsible for nonvesicular trafficking of ceramide. Proc. Natl. Acad. Sci. USA., 2008, 105(2), 488-493.

[37] Hanada, K.; Kumagai, K.; Yasuda, S.; Miura, Y.; Kawano, M.; Fukasawa, M.; Nishijima, M. Molecular machinery for nonvesicular trafficking of ceramide. Nature, 2003, 426(6968), 803-809.

[38] Tettamanti, G. Ganglioside/glycosphingolipid turnover: new concepts. Glycoconj. J., 2004, 20(5), 301-317.

[39] Stefanic, S.; Spycher, C.; Morf, L.; Fabrias, G.; Casas, J.; Schraner, E.; Wild, P.; Hehl, A.B.; Sonda, S. Inhibition of glucosylceramide synthesis affects cell cycle progression, membrane trafficking and stage differentiation in the minimized protozoan Giardia lamblia. J. Lipid Res., 2010, 51(9), 2527-2545.

[40] Halter, D.; Neumann, S.; van Dijk, S.M.; Wolthoorn, J.; de Maziere, A.M.; Vieira, O.V.; Mattjus, P.; Klumperman, J.; van Meer, G.; Sprong, H. Preand post-Golgi translocation of glucosylceramide in glycosphingolipid synthesis. J. Cell. Biol., 2007, 179(1), 101-115.

[41] Lannert, H.; Gorgas, K.; Meissner, I.; Wieland, F.T.; Jeckel, D. Functional organization of the Golgi apparatus in glycosphingolipid biosynthesis. Lactosylceramide and subsequent glycosphingolipids are formed in the lumen of the late Golgi. J. Biol. Chem., 1998, 273(5), 2939-2946.

[42] Carstea, E.D.; Murray, G.J.; O'Neill, R.R. Molecular and functional characterization of the murine glucocerebrosidase gene. Biochem. Biophys. Res. Commun., 1992, 184(3), 1477-1483.

[43] Galadari, S.; Wu, B.X.; Mao, C.; Roddy, P.; El Bawab, S.; Hannun, Y.A. Identification of a novel amidase motif in neutral ceramidase. Biochem. $J$. 2006, 393(Pt 3), 687-695.

[44] Xu, R.; Jin, J.; Hu, W.; Sun, W.; Bielawski, J.; Szulc, Z.; Taha, T.; Obeid, L.M.; Mao, C. Golgi alkaline ceramidase regulates cell proliferation and survival by controlling levels of sphingosine and S1P. FASEB J., 2006, 20(11), 1813-1825.

[45] Mao, C.; Obeid, L.M. Ceramidases: regulators of cellular responses mediated by ceramide, sphingosine, and sphingosine-1-phosphate. Biochim. Biophys. Acta., 2008, 1781(9), 424-434.

[46] Nikolova-Karakashian, M.; Merril, A.H. Ceramidases. Methods Enzymol., 2000, 311, 194-207.

[47] Hait, N.C.; Oskeritzian, C.A.; Paugh, S.W.; Milstien, S.; Spiegel, S. Sphingosine kinases, sphingosine 1-phosphate, apoptosis and diseases. Biochim Biophys. Acta., 2006, 1758(12), 2016-2026.

[48] Brindley, D.N. Lipid phosphate phosphatases and related proteins: signaling functions in development, cell division, and cancer. J. Cell Biochem., 2004, 92(5), 900-912.

[49] Mandala, S.M.; Thornton, R.; Tu, Z.; Kurtz, M.B.; Nickels, J.; Broach, J.; Menzeleev, R.; Spiegel, S. Sphingoid base 1-phosphate phosphatase: a key regulator of sphingolipid metabolism and stress response. Proc. Natl. Acad. Sci. USA., 1998, 95(1), 150-155.

[50] Bandhuvula, P.; Saba, J.D. Sphingosine-1-phosphate lyase in immunity and cancer: silencing the siren. Trends Mol. Med., 2007, 13(5), 210-217.

[51] Adam, D.; Heinrich, M.; Kabelitz, D.; Schutze, S. Ceramide: does it matter for T cells?. Trends Immunol., 2002, 23(1), 1-4.

[52] Venable, M.E., Lee, J.Y.; Smyth, M.J.; Bielawska, A.; Obeid, L.M. Role of ceramide in cellular senescence. J. Biol. Chem., 1995, 270(51), 3070130708.

[53] Hetz, C.A.; Hunn, M.; Rojas, P.; Torres, V.; Leyton, L.; Quest, A.F. Caspase-dependent initiation of apoptosis and necrosis by the Fas receptor in lymphoid cells: onset of necrosis is associated with delayed ceramide increase. J. Cell Sci., 2002, 115(Pt 23), 4671-4683.

[54] Chalfant, C.E.; Kishikawa, K.; Mumby, M.C.; Kamibayashi, C.; Bielawska, A.; Hannun, Y.A. Long chain ceramides activate protein phosphatase-1 and protein phosphatase-2A. Activation is stereospecific and regulated by phosphatidic acid. J. Biol. Chem., 1999, 274(29), 20313-20317.

[55] Ogretmen, B.; Hannun, Y.A. Biologically active sphingolipids in cancer pathogenesis and treatment. Nat. Rev. Cancer, 2004, 4(8), 604-616.

[56] Wolff, R.A.; Dobrowsky, R.T.; Bielawska, A.; Obeid, L.M.; Hannun, Y.A. Role of ceramide-activated protein phosphatase in ceramide-mediated signal transduction. J. Biol. Chem., 1994, 269(30), 19605-19609.

[57] Smyth, M.J.; Perry, D.K.; Zhang, J.; Poirier, G.G.; Hannun, Y.A.; Obeid, L.M. prICE: a downstream target for ceramide-induced apoptosis and for the inhibitory action of Bcl-2. Biochem. J., 1996, 316(Pt 1), 25-28.

[58] Wang, G.; Silva, J.; Krishnamurthy, K.; Tran, E.; Condie, B.G.; Bieberich, E. Direct binding to ceramide activates protein kinase Czeta before the formation of a pro-apoptotic complex with PAR-4 in differentiating stem cells. $J$. Biol. Chem., 2005, 280(28), 26415-26424. 
[59] Blazquez, C.; Galve-Roperh, I.; Guzman, M. De novo-synthesized ceramide signals apoptosis in astrocytes via extracellular signal-regulated kinase. FASEB J., 2000, 14(14), 2315-2322.

[60] Ruvolo, P.P. Intracellular signal transduction pathways activated by ceramide and its metabolites. Pharmacol. Res., 2003, 47(5), 383-392.

[61] Heinrich, M.; Wickel, M.; Schneider-Brachert, W.; Sandberg, C.; Gahr, J.; Schwandner, R.; Weber, T.; Saftig, P.; Peters, C.; Brunner, J.; Kronke, M.; Schutze, S. Cathepsin D targeted by acid sphingomyelinase-derived ceramide. EMBO J., 1999, 18(19), 5252-5263.

[62] Son, J.H.; Yoo, H.H.; Kim, D.H. Activation of de novo synthetic pathway of ceramides is responsible for the initiation of hydrogen peroxide-induced apoptosis in HL-60 cells. J. Toxicol. Environ. Health A., 2007, 70(15-16), 1310-1318.

[63] Devalapally, H.; Duan, Z.; Seiden, M.V.; Amiji, M.M. Modulation of drug resistance in ovarian adenocarcinoma by enhancing intracellular ceramide using tamoxifen-loaded biodegradable polymeric nanoparticles. Clin. Cancer Res., 2008, 14(10), 3193-3203.

[64] Wang, X.Z.; Beebe, J.R.; Pwiti, L.; Bielawska, A.; Smyth, M.J. Aberrant sphingolipid signaling is involved in the resistance of prostate cancer cell lines to chemotherapy. Cancer Res., 1999, 59(22), 5842-5848.

[65] Oh, J.E.; So, K.S.; Lim, S.J.; Kim, M.Y. Induction of apoptotic cell death by a ceramide analog in PC-3 prostate cancer cells. Arch. Pharm. Res., 2006, 29(12), 1140-1146.

[66] Bieberich, E.; Hu, B.; Silva, J; MacKinnon, S.; Yu, R.K.; Fillmore, H. Broaddus, W.C.; Ottenbrite, R.M. Synthesis and characterization of novel ceramide analogs for induction of apoptosis in human cancer cells. Cancer Lett., 2002; 181(1), 55-64.

[67] Bieberich, E.; Kawaguchi, T.; Yu, R.K. N-acylated serinol is a novel ceramide mimic inducing apoptosis in neuroblastoma cells. J. Biol. Chem., 2000, 275(1), 177-181.

[68] Koshkaryev, A.; Piroyan, A.; Torchilin, V.P. Increased apoptosis in cancer cells in vitro and in vivo by ceramides in transferrin-modified liposomes. Cancer Biol. Ther., 2012, 13(1), 50-60.

[69] Liu, X.; Ryland, L.; Yang, J.; Liao, A.; Aliaga, C.; Watts, R.; Tan, S.F.; Kaiser, J.; Shanmugavelandy, S.S.; Rogers, A.; Loughran, K.; Petersen, B.; Yuen, J.; Meng, F.; Baab, K.T.; Jarbadan, N.R.; Broeg, K.; Zhang, R.; Liao, J.; Sayers, T.J.; Kester, M.; Loughran, T.P. Targeting of survivin by nanoliposomal ceramide induces complete remission in a rat model of NKLGL leukemia. Blood, 2010, 116(20), 4192-4201.

[70] Stover, T.C.; Sharma, A.; Robertson, G.P.; Kester, M. Systemic delivery of liposomal short-chain ceramide limits solid tumor growth in murine models of breast adenocarcinoma. Clin. Cancer Res., 2005, 11(9), 3465-3474.

[71] Shabbits, J.A.; Mayer, L.D. High ceramide content liposomes with in vivo antitumor activity. Anticancer Res., 2003, 23(5A), 3663-3669.

[72] de Castro e Paula, L.A.; Hansen, P.J. Ceramide inhibits development and cytokinesis and induces apoptosis in preimplantation bovine embryos. Mol. Reprod. Dev., 2008, 75(6), 1063-1070.

[73] Huber, L.C.; Jungel, A.; Distler, J.H.; Moritz, F.; Gay, R.E.; Michel, B.A.; Pisetsky, D.S.; Gay, S.; Distler, O. The role of membrane lipids in the induction of macrophage apoptosis by microparticles. Apoptosis, 2007, 12(2), 363374 .

[74] Senkal, C.E.; Ponnusamy, S.; Bielawski, J.; Hannun, Y.A.; Ogretmen, B. Antiapoptotic roles of ceramide-synthase-6-generated C16-ceramide via selective regulation of the ATF6/CHOP arm of ER-stress-response pathways. FASEB J., 2010, 24(1), 296-308.

[75] Spiegel, S.; Milstien, S. Sphingosine-1-phosphate: an enigmatic signalling lipid. Nat. Rev. Mol. Cell Biol., 2003, 4(5), 397-407.

[76] Taha, T.A.; Argraves, K.M.; Obeid, L.M. Sphingosine-1-phosphate receptors: receptor specificity versus functional redundancy. Biochim. Biophys. Acta., 2004, 1682(1-3), 48-55.

[77] Spiegel, S.; English, D.; Milstien, S. Sphingosine 1-phosphate signaling: providing cells with a sense of direction. Trends. Cell Biol., 2002, 12(5), 236-242.

[78] Pyne, S.; Lee, S.C.; Long, J.; Pyne, N.J. Role of sphingosine kinases and lipid phosphate phosphatases in regulating spatial sphingosine 1-phosphate signalling in health and disease. Cell Signal., 2009, 2l(1), 14-21.

[79] Nishimura, H.; Akiyama, T.; Irei, I.; Hamazaki, S.; Sadahira, Y. Cellular localization of sphingosine-1-phosphate receptor 1 expression in the human central nervous system. J. Histochem. Cytochem., 2010, 58(9), 847-856.

[80] Young, N.; Van Brocklyn, J.R. Roles of sphingosine-1-phosphate (S1P) receptors in malignant behavior of glioma cells. Differential effects of S1P2 on cell migration and invasiveness. Exp. Cell Res., 2007, 313(8), 1615-1627. Payne, S.G.; Milstien, S.; Spiegel, S. Sphingosine-1-phosphate: dual messenger functions. FEBS Lett., 2002, 531(1), 54-57.

[82] Baran, Y.; Salas, A.; Senkal, C.E.; Gunduz, U.; Bielawski, J.; Obeid, L.M.; Ogretmen, B. Alterations of ceramide/sphingosine 1-phosphate rheostat involved in the regulation of resistance to imatinib-induced apoptosis in K562 human chronic myeloid leukemia cells. J. Biol. Chem., 2007, 282(15), 10922-10934.

[83] Cuvillier, O.; Pirianov, G.; Kleuser, B.; Vanek, P.G.; Coso, O.A.; Gutkind, S.; Spiegel, S. Suppression of ceramide-mediated programmed cell death by sphingosine-1-phosphate. Nature, 1996, 381(6585), 800-803.

[84] Olivera, A.; Spiegel, S. Sphingosine-1-phosphate as 2nd messenger in cell proliferation induced by PDGF and FCS mitogens. Nature, 1993, 365(6446), 557-560.
[85] Nava, V.E.; Hobson, J.P.; Murthy, S.; Milstien, S.; Spiegel, S. Sphingosine kinase type 1 promotes estrogen-dependent tumorigenesis of breast cancer MCF-7 cells. Exp. Cell Res., 2004, 281(1), 115-127.

[86] Thamilselvan, V.; Li, W.; Sumpio, B.E.; Basson, M.D. Sphingosine-1phosphate stimulates human Caco-2 intestinal epithelial proliferation via p38 activation and activates ERK by an independent mechanism. In Vitro Cell Dev. Biol. Anim., 2002, 38(4), 246-253.

[87] Nagahashi, M.; Ramachandran, S.; Kim, E.Y.; Allegood, J.C.; Rashid, O.M.; Yamada, A.; Zhao, R.; Milstien, S.; Zhou, H.; Spiegel, S.; Takabe, K. Sphingosine-1-phosphate produced by sphingosine kinase 1 promotes breast cancer progression by stimulating angiogenesis and lymphangiogenesis. Cancer Res., 2012, 72(3), 726-735.

[88] Heo, K.; Park, K.A.; Kim, Y.H.; Kim, S.H.; Oh, Y.S.; Kim, I.H.; Ryu, S.H.; Suh, P.G. Sphingosine 1-phosphate induces vascular endothelial growth factor expression in endothelial cells. BMB Rep., 2009, 42(10), 685690.

[89] Catarzi, S.; Giannoni, E.; Favilli, F.; Meacci, E.; Iantomasi, T.; Vincenzini, M.T. Sphingosine 1-phosphate stimulation of NADPH oxidase activity: relationship with platelet-derived growth factor receptor and c-Src kinase. Biochim. Biophys. Acta., 2007, 1770(6), 872-883.

[90] Maceyka, M.; Sankala, H.; Hait, N.C.; Le Stunff, H.; Liu, H.; Toman, R.; Collier, C.; Zhang, M.; Satin, L.S.; Merrill, A.H., Jr.; Milstien, S.; Spiegel, S. SphK1 and SphK2, sphingosine kinase isoenzymes with opposing functions in sphingolipid metabolism. J. Biol. Chem., 2005, 280(44), 37118-37129.

[91] Sweeney, E.A.; Sakakura, C.; Shirahama, T.; Masamune, A.; Ohta, H. Hakomori, S.; Igarashi, Y. Sphingosine and its methylated derivative N,Ndimethylsphingosine (DMS) induce apoptosis in a variety of human cancer cell lines. Int. J. Cancer, 1996, 66(3), 358-366.

[92] Kanno, T.; Nishizaki, T. Sphingosine induces apoptosis in hippocampal neurons and astrocytes by activating caspase-3/-9 via a mitochondrial pathway linked to SDK/14-3-3 Protein/Bax/Cytochrome c. J. Cell Physiol., 2011, 226(9), 2329-2337.

[93] Hannun, Y.A.; Loomis, C.R.; Merrill, A.H., Jr.; Bell, R.M. Sphingosine inhibition of protein kinase $\mathrm{C}$ activity and of phorbol dibutyrate binding in vitro and in human platelets. J. Biol. Chem., 1986, 261(27), 12604-12609.

[94] Sugiura, M.; Kono, K.; Liu, H.; Shimizugawa, T.; Minekura, H.; Spiegel, S.; Kohama, T. Ceramide kinase, a novel lipid kinase. Molecular cloning and functional characterization. J. Biol. Chem., 2002, 277(26), 23294-23300.

[95] Gomez-Munoz, A.; Duffy, P.A.; Martin, A.; O'Brien, L.; Byun, H.S.; Bittman, R.; Brindley, D.N. Short-chain ceramide-1-phosphates are novel stimulators of DNA synthesis and cell division: antagonism by cell-permeable ceramides. Mol. Pharmacol., 1995, 47(5), 833-839.

[96] Gangoiti, P.; Granado, M.H.; Arana, L.; Ouro, A.; Gomez-Munoz, A. Activation of protein kinase C-alpha is essential for stimulation of cell proliferation by ceramide 1-phosphate. FEBS Lett., 2010, 584(3), 517-524.

[97] Granado, M.H.; Gangoiti, P.; Ouro, A.; Arana, L.; Gomez-Munoz, A. Ceramide 1-phosphate inhibits serine palmitoyltransferase and blocks apoptosis in alveolar macrophages. Biochim. Biophys. Acta., 2009, 1791(4), 263-272.

[98] Gangoiti, P.; Granado, M.H.; Wang, S.W.; Kong, J.Y.; Steinbrecher, U.P.; Gomez-Munoz, A. Ceramide-1-phosphate stimulates macrophage proliferation through activation of the PI3- kinase/PKB, JNK and ERK1/2 pathways. Cell Signal., 2008, 20(4), 726-736.

[99] Signorelli, P.; Munoz-Olaya, J.M.; Gagliostro, V.; Casas, J.; Ghidoni, R. Fabrias, G. Dihydroceramide intracellular increase in response to resveratrol treatment mediates autophagy in gastric cancer cells. Cancer Lett., 2009, 282(2), 238-243.

[100] Kraveka, J.M.; Li, L.; Szulc, Z.M.; Bielawski, J.; Ogretmen, B.; Hannun, Y.A.; Obeid, L.M.; Bielawska, A. Involvement of dihydroceramide desaturase in cell cycle progression in human neuroblastoma cells. J. Biol. Chem., 2007, 282(23), 16718-16728.

[101] Neskovic, N.M.; Rebel, G.; Harth, S.; Mandel, P. Biosynthesis of galactocerebrosides and glucocerebrosides in glial cell lines. J. Neurochem., 1981, 37(6), 1363-1370.

[102] Li, R.; Manela, J.; Kong, Y.; Ladisch, S. Cellular gangliosides promote growth factor-induced proliferation of fibroblasts. J. Biol. Chem., 2000, 275(44), 34213-34223.

[103] Lucci, A.; Cho, W.I.; Han, T.Y.; Giuliano, A.E.; Morton, D.L.; Cabot, M.C. Glucosylceramide: a marker for multipledrug resistant cancers. Anticancer Res., 1998, 18(1B), 475-480.

[104] Liu, Y.Y.; Gupta, V.; Patwardhan, G.A.; Bhinge, K.; Zhao, Y.; Bao, J.; Mehendale, H.; Cabot, M.C.; Li, Y.T.; Jazwinski, S.M. Glucosylceramide synthase upregulates MDR1 expression in the regulation of cancer drug resistance through cSrc and beta-catenin signaling. Mol. Cancer, 2010, 9, 145.

[105] Song, M.; Zang, W.; Zhang, B.; Cao, J.; Yang, G. GCS overexpression is associated with multidrug resistance of human HCT-8 colon cancer cells. $J$ Exp. Clin. Cancer Res., 2012, 31(1), 23.

[106] Lavie, Y.; Cao, H.; Bursten, S.L.; Giuliano, A.E.; Cabot, M.C. Accumulation of glucosylceramides in multidrug-resistant cancer cells. J. Biol. Chem. 1996, 27l(32), 19530-19536.

[107] Apraiz, A.; Idkowiak-Baldys, JK.; Boyano, M.D.; Pérez-Yarza, G.; Hannun, Y.A.; Asumendi A. Evaluation of bioactive sphingolipids in 4-HPR-resistant leukemia cells. BMC Cancer, 2011, $11,477$.

[108] Xie, P.; Shen, Y.F.; Shi, Y.P.; Ge, S.M.; Gu, Z.H.; Wang, J.; Mu, H.J.; Zhang, B.; Qiao, W.Z.; Xie, K.M. Overexpression of glucosylceramide synthase in associated with multidrug resistance of leukemia cells. Leuk. Res., 
2008, 32(3), 475-480.

[109] Gouazé, V.; Liu, Y.Y.; Prickett, C.S.; Yu, J.Y.; Giuliano, A.E.; Cabot, M.C. Glucosylceramide synthase blockade down-regulates P-glycoprotein and resensitizes multidrug-resistant breast cancer cells to anticancer drugs. Cancer Reserch., 2005, 65(9), 3861-3867.

[110] Grazide, S.; Terrisse, A.D.; Lerouge, S.; Laurent, G.; Jaffrézou, J.P. Cytoprotective effect of glucosylceramide synthase inhibition against daunorubicininduced apoptosis in human leukemic cell lines. J. Biol. Chem., 2004, 30(279), 18256-18261.

[111] Maurer, B.J.; Melton, L.; Billups, C.; Cabot, M.C.; Reynolds, C.P. Synergistic cytotoxicity in solid tumor cell lines between N-(4-hydroxy phenyl)retinamide and modulators of ceramide metabolism. J. Natl. Cancer Inst., 2000, 92(23), 1897-1909.

[112] Hug, P.; Lin, H.M.; Korte, T.; Xiao, X.; Dimitrov, D.S.; Wang, J.M.; Puri, A.; Blumenthal, R., Glycosphingolipids promote entry of a broad range of human immunodeficiency virus type 1 isolates into cell lines expressing CD4, CXCR4, and/or CCR5. J. Virol., 2000, 74(14), 6377-6385.

[113] Chan, S.Y.; Hilchie, A.L.; Brown, M.G.; Anderson, R.; Hoskin, D.W. Apoptosis induced by intracellular ceramide accumulation in MDA-MB-435 breast carcinoma cells is dependent on the generation of reactive oxygen species. Exp. Mol. Pathol., 2007, 82(1), 1-11.

[114] Kartal, M.; Saydam, G.; Sahin, F.; Baran, Y. Resveratrol triggers apoptosis through regulating ceramide metabolizing genes in human K562 chronic myeloid leukemia cells. Nutr. Cancer, 2011, 63(4), 637-644.

[115] Cakir, Z.; Saydam, G.; Sahin, F.; Baran, Y. The roles of bioactive sphingolipids in resveratrol-induced apoptosis in HL60: acute myeloid leukemia cells. J. Cancer Res. Clin. Oncol., 2011, 137(2), 279-286.

[116] Baran, Y.; Bielawsk,i J.; Gunduz, U.; Ogretmen, B. Targeting glucosylceramide synthase sensitizes imatinib-resistant chronic myeloid leukemia cells via endogenous ceramide accumulation. J. Cancer Res. Clin. Oncol., 2011, 137(10), 1535-1544.

[117] Camgoz, A.; Gencer, E.B.; Ural, A.U.; Avcu, F.; Baran, Y. Roles of ceramide synthase and ceramide clearence genes in nilotinib-induced cell death in chronic myeloid leukemia cells. Leuk. Lymphoma., 2011, 52(8), 15741584 .

[118] Gencer, E.B.; Ural, A.U.; Avcu, F.; Baran, Y. A novel mechanism of dasatinib-induced apoptosis in chronic myeloid leukemia; ceramide synthase and ceramide clearance genes. Ann. Hematol., 2011, 90(11), 1265-1275.

[119] Bassoy, E.Y.; Baran, Y. Bioactive sphingolipids in docetaxel-induced apoptosis in human prostate cancer cells. Biomed. Pharmacother, 2012, 66(2), 103-110

[120] Hara, S.; Nakashima, S; Kiyono, T.; Sawada, M.; Yoshimura, S.; Iwama, T.; Sakai, N. Ceramide triggers caspase activation during gamma-radiationinduced apoptosis of human glioma cells lacking functional p53. Oncol. Rep., 2004, 12(1), 119-123.

[121] Huang, W.C.; Tsai, C.C.; Chen, C.L.; Chen, T.Y.; Chen, Y.P.; Lin, Y.S.; Lu, P.J.; Lin, C.M.; Wang, S.H.; Tsao, C.W.; Wang, C.Y.; Cheng, Y.L.; Hsieh, C.Y.; Tseng, P.C.; Lin, C.F. Glucosylceramide synthase inhibitor PDMP sensitizes chronic myeloid leukemia T315I mutant to Bcr-Abl inhibitor and cooperatively induces glycogen synthase kinase-3-regulated apoptosis. FASEB J., 2011, 25(10), 3661-3673.

[122] Kolmakova, A.; Rajesh, M.; Zang, D.; Pili, R.; Chatterjee, S. VEGF recruits lactosylceramide to induce endothelial cell adhesion molecule expression and angiogenesis in vitro and in vivo. Glycoconj. J., 2009, 26(5), 547-558.

[123] Dijkhuis, A.J.; Klappe, K.; Jacobs, S.; Kroesen, B.J.; Kamps, W.; Sietsma, H.; Kok, J.W. PDMP sensitizes neuroblastoma to paclitaxel by inducing aberrant cell cycle progression leading to hyperploidy. Mol. Cancer Ther., 2006, 5(3), 593-601.

[124] di Bartolomeo, S.; Spinedi, A. Differential chemosensitizing effect of two glucosylceramide synthase inhibitors in hepatoma cells. Biochem. Biophys. Res. Commun., 2001, 288(1), 269-274.

[125] Dijkhuis, A.J.; Klappe, K.; Kamps, W.; Sietsma, H.; Kok, J.W. Gangliosides do not affect ABC transporter function in human neuroblastoma cells. $J$. Lipid Res., 2006, 47(6), 1187-1195.

[126] Chai, L.; McLaren, R.P.; Byrne, A.; Chuang, W.L.; Huang, Y.; Dufault, M.R.; Pacheco, J.; Madhiwalla, S.; Zhang; X.; Zhang, M.; Teicher, B.A.; Carter, K.; Cheng, S.H.; Leonard, J.P.; Xiang, Y.; Vasconcelles, M.; Goldberg, M.A.; Copeland, D.P.; Klinger, K.W.; Lillie, J.; Madden, S.L.; Jiang, Y.A. The chemosensitizing activity of inhibitors of glucosylceramide synthase is mediated primarily through modulation of P-gp function. Int. J. Oncol., 2011, 38(3), 701-711.

[127] Bieberich, E.; Freischütz, B.; Suzuki, M.; Yu, R.K. Differential effects of glycolipid biosynthesis inhibitors on ceramide-induced cell death in neuroblastoma cells. J. Neurochem., 1999, 72(3), 1040-1049.

[128] Guerrera, M.; Ladisch, S. N-butyldeoxynojirimycin inhibits murine melanoma cell ganglioside metabolism and delays tumor onset. Cancer Lett., 2003, 201(1), 31-40.

[129] Dijkhuis, A.J.; Klappe, K.; Kamps, W.; Sietsma, H.; Kok, J.W. Gangliosides do not affect ABC transporter function in human neuroblastoma cells. $J$. Lipid Res., 2006, 47(6), 1187-1195.

[130] Aravind, A.; Sankar, M.G.; Varghese, B.; Baskaran, S. Regioselective reductive cleavage of bis-benzylidene acetal: stereoselective synthesis of anticancer agent OGT2378 and glycosidase inhibitor 1,4-dideoxy-1,4-imino-lxylitol. J. Org. Chem., 2009, 74(7), 2858-2561.

[131] Weiss, M.; Hettmer, S.; Smith, P.; Ladisch, S. Inhibition of melanoma tumor growth by a novel inhibitor of glucosylceramide synthase. Cancer Res., 2003, 63(13), 3654-3658.

[132] French, K.J.; Schrecengost, R.S.; Lee, B.D.; Zhuang, Y.; Smith, S.N Eberly, J.L.; Yun, J.K.; Smith, C.D. Discovery and evaluation of inhibitors of human sphingosine kinase. Cancer Res., 2003, 63(18), 5962-5969.

[133] Antoon, J.W.; White, M.D.; Burow, M.E.; Beckman, B.S. Dual inhibition of sphingosine kinase isoforms ablates TNF-induced drug resistance. Oncol. Rep., 2012, 27(6), 1779-1786.

[134] French, K.J.; Upson, J.J.; Keller, S.N.; Zhuang, Y.; Yun, J.K.; Smith, C.D. Antitumor activity of sphingosine kinase inhibitors. J. Pharmacol. Exp. Ther., 2006, 318(2), 596-603.

[135] Beljanski, V.; Lewis, C.S.; Smith, C.D., Antitumor activity of sphingosine kinase 2 inhibitor ABC294640 and sorafenib in hepatocellular carcinoma xenografts. Cancer Biol. Ther., 2011, 11(5), 524-534.

[136] French, K.J.; Zhuang, Y.; Maines LW, Gao P, Wang, W.; Beljanski, V.; Upson, J.J.; Green, C.L.; Keller, S,N.; Smith, C.D. Pharmacology and antitumor activity of ABC294640, a selective inhibitor of sphingosine kinase-2. J. Pharmacol. Exp. Ther, 2010, 333(1), 129-139.

[137] Beljanski, V.; Knaak, C.; Smith, C.D. A novel sphingosine kinase inhibitor induces autophagy in tumor cells. J. Pharmacol. Exp. Ther, 2010, 333(2), 454-464.

[138] Paugh, S.W.; Paugh, B.S.; Rahmani, M.; Kapitonov, D.; Almenara, J.A.; Kordula, T.; Milstien, S.; Adams, J.K.; Zipkin, R.E.; Grant, S.; Spiegel, S. A selective sphingosine kinase 1 inhibitor integrates multiple molecular therapeutic targets in human leukemia. Blood, 2008, 112(4), 1382-1391.

[139] Pyne, S.; Bittman, R.; Pyne, N.J. Sphingosine kinase inhibitors and cancer: seeking the golden sword of Hercules. Cancer Res., 2011, 71(21), 6576 6582.

[140] Lim, K.G.; Tonelli, F.; Berdyshev, E.; Gorshkova, I.; Leclercq, T.; Pitson, S.M.; Bittman, R.; Pyne, S.; Pyne, N.J. Inhibition kinetics and regulation of sphingosine kinase 1 expression in prostate cancer cells: Functional differences between sphingosine kinase 1a and 1b. Int. J. Biochem. Cell Biol., 2012 [Epub ahead of print]

[141] Lim, K.G.; Sun, C.; Bittman, R.; Pyne, N.J.; Pyne, S. (R)-FTY720 methyl ether is a specific sphingosine kinase 2 inhibitor: Effect on sphingosine kinase 2 expression in HEK 293 cells and actin rearrangement and survival of MCF-7 breast cancer cells. Cell Signal., 2011, 23(10), 1590-1595.

[142] Liu, S.Q.; Huang, J.A.; Qin, M.B.; Su, Y.J.; Lai, M.Y.; Jiang, H.X.; Tang, G.D. Sphingosine kinase 1 enhances colon cancer cell proliferation and invasion by upregulating the production of MMP-2/9 and uPA via MAPK pathways. Int. J. Colorectal Dis., 2012 [Epub ahead of print]

[143] Liu, S.Q.; Qin, M.B.; Huang, J.A.; Zhong, Y.Y.; Tang, G.D.; Jiang, H.X. Effect of sphingosine kinase 1 on the apoptosis, migration and invasion of colon cancer HT-29 cells and its molecular mechanisms. Zhonghua Zhong Liu. Za. Zhi., 2011 33(3), 178-182.

[144] Schnute, M.E.; McReynolds, M.D.; Kasten, T.; Yates, M.; Jerome, G.; Rains, J.W.; Hall, T.; Chrencik, J.; Kraus, M.; Cronin, C.N.; Saabye, M.; Highkin, M.K.; Broadus, R.; Ogawa, S.; Cukyne, K.; Zawadzke, L.E.; Peterkin, V.; Iyanar, K.; Scholten, J.A.; Wendling, J.; Fujiwara, H.; Nemirovskiy, O.; Wittwer, A.J.; Nagiec, M.M. Modulation of cellular S1P levels with a novel, potent and specific inhibitor of sphingosine kinase-1. Biochem. J., 2012, 444(1), 79-88.

[145] Dickson, M.A.; Carvajal, R.D.; Merrill, A.H. Jr; Gonen, M.; Cane, L.M.; Schwartz, G.K. A phase I clinical trial of safingol in combination with cisplatin in advanced solid tumors. Clin. Cancer Res., 2011, 17(8), 2484-2492.

[146] Coward, J.; Ambrosini, G.; Musi, E.; Truman, J.P.; Haimovitz-Friedman, A.; Allegood, J.C. Safingol (L-threo-sphinganine) induces autophagy in solid tumor cells through inhibition of PKC and the PI3-kinase pathway. Auto phagy, 2009, 5, 184-193.

[147] Schwartz, G.K.; Ward, D.; Saltz, L.; Casper, E.S.; Spiess, T.; Mullen, E. A pilot clinical/pharmacological study of the protein kinase C-specific inhibito safingol alone and in combination with doxorubicin. Clin. Cancer Res. 1997, 3, 537-543.

[148] Stevenson, C.E.; Takabe, K.; Nagahashi, M.; Milstien, S.; Spiegel, S. Targeting Sphingosine-1-Phosphate in Hematologic Malignancies. Anticancer Agents Med. Chem., 2011, 11(9), 794-798.

[149] Brinkmann, V.; Davis, M.D.; Heise, C.E.; Albert, R.; Cottens, S.; Hof, R.; Bruns, C. The immune modulator FTY720 targets sphingosine 1-phosphate receptors. J. Biol. Chem., 2002, 277, 21453-21457.

[150] Pyne, N.J.; Pyne, S. Sphingosine 1-phosphate and cancer. Nature Rev. Cance., 2010, 10, 489-503.

[151] Kennedy, P.C.; Zhu, R.; Huang, T.; Tomsig, J.L.; Mathews, T.P.; David, M.; Peyruchaud, O.; Macdonald, T.L.; Lynch, K.R. Characterization of a sphingosine 1-phosphate receptor antagonist prodrug. J. Pharmacol. Exp. Ther. 2011, 338(3), 879-889.

[152] Sabbadini, R.A. Sphingosine-1-phosphate antibodies as potential agents in the treatment of cancer and age-related macular degeneration. Br. J. Phar macol., 2011, 162(6), 1225-1238.

[153] Visentin, B.; Vekich, J.A.; Sibbald, B.J.; Cavalli, A.L.; Moreno, K.M.; Matteo, R.G.; Garland, W.A.; Lu, Y.; Yu, S.; Hall, H.S.; Kundra ,V.; Mills, G.B.; Sabbadini, R.A. Validation of an anti-sphingosine-1-phosphate antibody as a potential therapeutic in reducing growth, invasion, and angiogenesis in multiple tumor lineages. Cancer Cell., 2006, 9(3), 225-238.

[154] O'Brien, N.; Jones, S.T.; Williams, D.G.; Cunningham, H.B.; Moreno, K.; Visentin, B.; Gentile, A.; Vekich, J.; Shestowsky, W.; Hiraiwa, M.; Matteo, 
R.; Cavalli, A.; Grotjahn, D.; Grant, M.; Hansen, G.; Campbell, M.A.; Sabbadini, R. Production and characterization of monoclonal anti-sphingosine-1phosphate antibodies. J. Lipid Res., 2009, 50(11), 2245-2257.

[155] Gordon, M.S.; Just, R.; Rosen, L.S.; Dorr, A. A phase I study of sonepcizumab (S), a humanized monoclonal antibody to sphingosine-1-phosphate (S1P), in patients with advanced solid tumors. J. Clin. Oncol., 2010, 28, 15s(suppl; abstr 2560).

[156] Franzen, R.; Pautz, A.; Brautigam, L.; Geisslinger, G.; Pfeilschifter, J.; Huwiler, A. Interleukin-1beta induces chronic activation and de novo synthesis of neutral ceramidase in renal mesangial cells. J. Biol. Chem., 2001, 276, 35382-35389.

[157] Elojeimy, S.; Liu, X.; McKillop, J.C.; El-Zawahry, A.M.; Holman, D.H.; Cheng, J.Y.; Meacham, W.D.; Mahdy, A.E.; Saad, A.F.; Turner, L.S.; Cheng, J., A Day T.; Dong, J.Y.; Bielawska. A.; Hannun, Y.A.; Norris, J.S. Role of acid ceramidase in resistance to FasL: Therapeutic approaches based on acid ceramidase inhibitors and FasL gene therapy. Mol. Ther, 2007, 15(7), 1259-63.

[158] Holman, D.H.; Turner, L.S.; El-Zawahry, A.; Elojeimy, S.; Liu, X.; Bielawski, J.; Szulc, Z.M.; Norris, K.; Zeidan, Y.H.; Hannun, Y.A.; Bielawska, A.; Norris, J.S. Lysosomotropic acid ceramidase inhibitor induces apoptosis in prostate cancer cells. Cancer Chemother. Pharmacol., 2008, 61(2), 231-42.

[159] Bielawska, A.; Greenberg, M.S.; Perry, D.; Jayadev, S.; Shayman, J.A.; McKay, C.; Hannun, Y.A. (1S,2R)-D-erythro-2-(N-Myristoylamino)-1phenyl-1-propanol as an inhibitor of ceramidase. J. Biol. Chem., 1996, 271, 12646-12654.

[160] Raisova, M.; Goltz, G.; Bektas, M.; Bielawska, A.; Riebeling, C.; Hossini, A.M.; Eberle, J.; Hannun, Y.A.; Orfanos, C.E.; Geilen, C.C. Bcl-2 overexpression prevents apoptosis induced by ceramidase inhibitors in malignant melanoma and HaCaT keratinocytes. FEBS Lett., 2002, 516(1-3), 47-52.

[161] Rodriguez-Lafrasse, C.; Alphonse, G.; Aloy, M.T.; Ardail, D.; Gérard, J.P.; Louisot, P.; Rousson, R. Increasing endogenous ceramide using inhibitors of sphingolipid metabolism maximizes ionizing radiation-induced mitochondrial injury and apoptotic cell killing. Int. J. Cancer., 2002, 101, 589-598.

[162] Alphonse, G.; Bionda, C.; Aloy, M.T.; Ardail, D.; Rousson, R.; RodriguezLafrasse, C. Overcoming resistance to gamma-rays in squamous carcinoma cells by poly-drug elevation of ceramide levels. Oncogene, 2004, 23(15), 2703-2715.

[163] Saad, A.F.; Meacham, W.D.; Bai, A.; Anelli, V.; Elojeimy, S.; Mahdy, A.E.; Turner, L.S.; Cheng, J.; Bielawska, A.; Bielawski, J.; Keane, T.E.; Obeid, L.M.; Hannun, Y.A.; Norris, J.S.; Liu, X. The functional effects of acid ceramidase overexpression in prostate cancer progression and resistance to chemotherapy. Cancer Biol. Ther., 2002, 6(9) , 1455-1460.

[164] Liu, X.; Elojeimy, S.; Turner, L.S.; Mahdy, A.E.; Zeidan, Y.H.; Bielawska, A.; Bielawski, J.; Dong, J.Y.; El-Zawahry, A.M.; Guo, G.W.; Hannun, Y.A.; Holman, D.H.; Rubinchik, S.; Szulc, Z.; Keane, T.E.; Tavassoli, M.; Norris, J.S. Acid ceramidase inhibition: a novel target for cancer therapy, Front. Bioscience, 2008, 13(6), 2293-2298.

[165] Selzner, M.; Bielawska,, A.; Morse, M.A.; Rüdiger, H.A.; Sindram, D.; Hannun, Y.A.; Clavien, P.A. Induction of apoptotic cell death and prevention of tumor growth by ceramide analogues in metastatic human colon cancer. Cancer Res., 2001, 61(3), 1233-1240.

[166] Samsel, L.; Zaidel, G.; Drumgoole, H.M.; Jelovac, D.; Drachenberg, C.; Rhee, J.G.; Brodie, A.M.; Bielawska, A.; Smyth, M.J. The ceramide ana$\log , \mathrm{B} 13$, induces apoptosis in prostate cancer cell lines and inhibits tumor growth in prostate cancer xenografts. Prostate, 2004, 58(4), 382-393.

[167] Cuvillier, O.; Levade, T. Enzymes of sphingosine metabolism as potential pharmacological targets for therapeutic intervention in cancer. Pharm. Res, 2003, 47(5), 439-445.

[168] Spinedi, A.; Di Bartolomeo, S.; Piacentini, M. N-Oleoylethanolamine inhibits glucosylation of natural ceramides in CHP-100 neuroepithelioma cells: possible implications for apoptosis. Bioch. Biophy. Res. Commun., 1999, 255(2), 456-459.

[169] Tavarini, S.; Colombaioni, L.; Garcia-Gil, M. Sphingomyelinase metabolites control survival and apoptotic death in SH-SY5Y neuroblastoma cells. Neurosci. Lett., 2000, 285(3), 185-188.

[170] Noda, S.; Yoshimura, S.; Sawada, M.; Naganawa, T.; Iwama, T.; Nakashima, S.; Sakai, N. Role of ceramide during cisplatin induced apoptosis in C6 glioma cells. J. Neurooncology, 2001, 52(1), 11-21.

[171] Morales, A.; Parıs, R.; Villanueva, A.; Llacuna, L.; Garcia-Ruiz, C.; Fernandez-Checa, J.C. Pharmacological inhibition or small interfering RNA targeting acid ceramidase sensitizes hepatoma cells to chemotherapy and reduces tumor growth in vivo. Oncogene, 2007, 26(6), 905-916.

[172] Grijalvo, S.; Bedia, C.; Triola, G.; Casas, J.; Llebaria, A.; Teixidó, J.; Rabal, O.; Levade, T.; Delgado, A.; Fabriàs, G. Design, synthesis and activity as acid ceramidase inhibitors of 2-oxooctanoyl and N-oleoylethanolamine analogues. Chem. Phys. Lipids., 2006, 144(1), 69-84.

[173] Bediaa, C.; Canalsa, D.; Mataboscha, X.; Harraka, Y.; Casasa, J.; Llebariaa, A.; Delgadoa, A.; Fabriása, G. Cytotoxicity and acid ceramidase inhibitory activity of 2-substituted aminoethanol amides. Chem. Phys. Lipids., 2008, 156(1-2), 33-40.

[174] Gouazé-Andersson, V.; Flowers, M.; Karimi, R.; Fabriás, G.; Delgado, A.; Casas, J.; Cabot, M.C. Inhibition of acid ceramidase by a 2-substituted aminoethanol amide synergistically sensitizes prostate cancer cells to $\mathrm{N}$-(4hydroxyphenyl) retinamide. Prostate, 2011, 71(10), 1064-1073.
[175] Flowers, M. Fabria 's, G.; Delgado, A · Casas, J ; Abad, J.L.; Cabot, M.C. C6-ceramide and targeted inhibition of acid ceramidase induce synergistic decreases in breast cancer cell growth. Breast Cancer Research Treat., 2012, 133(2), 447-458.

[176] Mahdy, A.E.; Cheng, J.C.; Li, J.; Elojeimy, S.; Meacham, W.D.; Turner, L.S.; Bai, A.; Gault, C.R.; McPherson, A.S.; Garcia, N.; Beckham, T.H.; Saad, A.; Bielawska, A.; Bielawski, J.; Hannun, Y.A.; Keane, T.E.; Taha, M.I.; Hammouda, H.M.; Norris, J.S.; Liu, X. Acid ceramidase upregulation in prostate cancer cells confers resistance to radiation: AC inhibition, a potential radiosensitizer. Mol. Therapy, 2009, 17(3), 430-438.

[177] Bai, A.; Szulc, Z.M.; Bielawski, J.; Mayroo, N.; Liu, X.; Norris, J.; Hannun, Y.A.; Bielawska, A. Synthesis and bioevaluation of omega-N-amino analogs of B13. Bioorg. Med. Chem., 2009, 17(5), 1840-1848.

[178] Lee, S.K.; Park, S.M.; Im, C. Cytotoxicities and quantitative structure activity relationships of B13 sulfonamides in HT-29 and A549 cells. Korean J. Physiol. Pharmacol., 2011, 15(6), 423-429.

[179] Kolesnick, R.N.; Krönke, M. Regulation of ceramide production and apoptosis. Annu. Rev. Physiol, 1998, 60, 643-65.

[180] Macchia, M.; Bertini, S.; Fogli, S.; Giovannetti, E.; Minutolo, F.; Rapposelli, S.; Danesi, R. Ceramide analogues in apoptosis: a new strategy for anticance drug development. Farmaco., 2003, 58(3), 205-211.

[181] Bittman, R. Synthetic sphingolipids as bioactive molecules: roles in regulation of cell function. Wiley encyclopedia, 2008.

[182] Sakai, T.; Koezuka, Y. Ceramide derivatives as therapeutic agents. Exp. Opin. On Ther. Patents, 1998, 8(12), 1673-1682.

[183] Radin, N.S. Killing cancer cells by poly-drug elevation of ceramide levels: A hypothesis whose time has come? Eur. J. Biochem., 2001, 268(2), 193-204.

[184] Geley, S.; Hartmann, B.L.; Kofler, R. Ceramides induce a form of apoptosis in human acute lymphoblastic leukemia cells that is inhibited by Bcl-2, but not by CrmA. FEBS Lett., 1997, 400(1), 15-18.

[185] Kuroki, J.; Hirokawa, M.; Kitabayashi, A.; Lee, M.; Horiuchi, T.; Kawabata, Y.; Miura, A.B. Cell-permeable ceramide inhibits the growth of B lymphoma Raji cells lacking TNF-alpha-receptors by inducing G0/G1 arrest but not apoptosis: a new model for dissecting cell-cycle arrest and apoptosis. Leukemia, 1996, 10(12), 1950-8.

[186] Cuvillier, O.; Rosenthal, D. S.; Smulson, M. E.; Spiegel, S. J. Sphingosine 1phosphate inhibits activation of caspases that cleave poly (ADP-ribose) polymerase and lamins during Fas- and ceramide-mediated apoptosis in Jurkat T lymphocytes. Biol. Chem, 1998, 273(5), 2910-2916.

[187] Shikata, K.; Niiro, H.; Azuma, H.; Ogino, H.; Tachibana, T. Apoptotic activities of C2-ceramide and C2-dihydroceramide homologs against HL-60 cells. Bioorg. Med. Chem., 2003, 11(13), 2723-2728.

[188] Fillet, M.; Bentires-Alj, M.; Deregowski, V.; Greimers, R.; Gielen, J.; Piette, J.; Bours, V.; Merville, M.P. Mechanisms involved in exogenous C2- and C6-ceramide-induced cancer cell toxicity. Biochem. Pharmac., 2003, 65(10), 1633-1642.

[189] Charles, A.G.; Han, T.Y.; Liu, Y.Y.; Hansen, N.; Giuliano, A.E.; Cabot, M.C. Taxol-induced ceramide generation and apoptosis in human breast cancer cells. Cancer Chemot. Pharmac, 2001, 47(5), 444-450.

[190] Ji, C.; Yang, B.; Yang, Y.L.; He, S.H.; Miao, D.D.; He, L.; Bi, Z.G. Exogenous cell-permeable C6 ceramide sensitizes multiple cancer cell lines to Doxorubicin-induced apoptosis by promoting AMPK activation and mTORC1 inhibition. Oncogene, 2010, 29(50), 6557-6568.

[191] Zhu, O. Y.; Wang, Z.; Ji, C.; Cheng, L.; Yang, Y. L.; Ren, L.; Jin, Y.H.; Wang, Q.J.; Gu, X. J.; Bi, Z. G.; Hu, G.; Yang, Y. C6-ceramide synergistically potentiates the anti-tumor effects of histone deacetylase inhibitors via Akt dephosphorylation and a-tubulin hyperacetylation both in vitro and in vivo. Cell Death Dis., 2011, 2, e117.

[192] Karasawas, N.; Erukulla, R. K.; Bittman, R.; Lockshin, R · Zakeri, Z. Stereospecific induction of apoptosis in U937 cells by N-octanoyl-sphingosine stereoisomers and N-octyl-sphingosine. The ceramide amide group is not required for apoptosis. Eur. J. Biochem, 1996, 236(2), 729-737.

[193] Wieder, T.; Geilen, C. C.; Kolter, T.; Sadeghlar, F.; Sandhoff, K.; Brossmer, R.; Ihrig, P.; Perry, D.; Orfanos, C.E.; Hannun, Y.A. Bcl-2 antagonizes apoptotic cell death induced by two new ceramide analogues. FEBS Lett., 1997, 411(2-3), 260-264.

[194] Crawford, K. W.; Bittman, R.; Chun, J.; Byun, H.S.; Bowen, W.D. Novel ceramide analogues display selective cytotoxicity in drug-resistant breast tumor cell lines compared to normal breast epithelial cells. Cell Mol. Biol., 2003, 49(7), 1017-1023.

[195] Struckhoff, A.P,; Bittman. R.; Burow M. E.; Clejan. S.; Elliott S.; Hammond, T.; Tang, Y.; Beckman, B.S. Novel ceramide analogs as potential chemotherapeutic agents in breast cancer. J. Pharmacol. Exp. Ther, 2004, 309(2), 523-532.

[196] Antoon, J. W.; Liu, J.; Gestaut, M. M.; Burow, M.E.; Beckman, B.S.; Foroozesh, M. Design, synthesis, and biological activity of a family of novel ceramide analogues in chemoresistant breast cancer cells. J. Med. Chem. 2009, 24(18), 5748-5752.

[197] Ha, H.J.; Hong, M.C.; Ko, S.W.; Kim, Y.W.; Lee, W.K.; Park, J. Synthesis of constrained ceramide analogs and their potent antileukemic activities. Bioorg. Med. Chem. Lett., 2006, 16(7), 1880-1883.

[198] Granot, T.; Milhas, D.; Carpentier, S.; Dagan, A.; Se'gui, B.; Gatt, S.; Levade, T. Caspase-dependent and -independent cell death of Jurkat human leukemia cells induced by novel synthetic ceramide analogs. Leukemia, 2006, 20(3), 392-399. 
[199] Dagan, A.; Wanga,C.; Fibachb, E.; Gatt, S. Synthetic, non-natural sphingolipid analogs inhibit the biosynthesis of cellular sphingolipids, elevate ceramide and induce apoptotic cell death. Bioch. Biophy. Acta, 2003, 1633(3), $161-169$.

[200] Novgorodov, S.A.; Szulc, Z.M.; Luberto, C.; Jones, J.A.; Bielawski, J.; Bielawska, A.; Hannun, Y.A.; Obeid, L.M. Positively charged ceramide is a potent inducer of mitochondrial permeabilization. J. Biol. Chem., 2005, 280(16), 16096-16105.

[201] Ponnusamy, S.; Meyers-Needham, M.; Senkal, C.E.; Saddoughi, S.A.; Sentelle, D.; Selvam, S.P.; Salas, A.; Ogretmen, B. Sphingolipids and cancer: ceramide and sphingosine-1- phosphate in the regulation of cell death and drug resistance. Fut. Oncol., 2010, 6(10), 1603-1624.

[202] Senkal, C.E.; Ponnusamy, S.; Rossi, M.J.; Sundararaj, K.; Szulc, Z.; Bielawski, J.; Bielawska, A.; Meyer, M.; Cobanoglu, B.; Koybasi, S.; Sinha, D.; Day, T.A.; Obeid, L.M.; Hannun, Y.A.; Ogretmen, B. Potent antitumor activity of a novel cationic pyridinium ceramide alone or in combination with gemcitabine against human head and neck squamous cell carcinomas in vitro and in vivo. J. Pharmacol. Exp. Ther, 2006, 317(3), 1188-1199.

[203] Rossi, M.J.; Sundararaj, K.; Koybasi, S.; Phillips, M.S.; Szulc, Z.M.; Bielawska, A.; Day, T.A.; Obeid, L.M.; Hannun, Y.A.; Ogretmen, B. Inhibition of growth and telomerase activity by novel cationic ceramide analogs with high solubility in human head and neck squamous cell carcinoma cells. Otolaryngol Head Neck Surg., 2005, 132(1), 55-62.

[204] Separovic, D.; Bielawski, J.; Pierce, J.S.; Merchant, S.; Tarca, A.L. ; Bhatti, G.; Ogretmen, B.; Korbelik, M. Enhanced tumor cures after Foscan photodynamic therapy combined with the ceramide analog Lcl29. Evidence from mouse squamous cell carcinomas for sphingolipids as biomarkers of treatment response. Int. J. Oncol., 2011, 38(2), 521-527.

[205] Separovic, D.; Bielawski, J.; Pierce, J.S.; Merchant, S.; Tarca, A.L.; Ogretmen, B.; Korbelik, M. Increased tumour dihydroceramide production after Photofrin-PDT alone and improved tumour response after the combination with the ceramide analogue LCL29. Evidence from mouse squamous cell carcinomas. Br. J. Cancer, 2009, 100(4), 626-632.

[206] Dindo, D.; Dahm, F.; Szulc, Z.; Bielawska, A.; Obeid, L.M.; Hannun, Y.A.; Graf, R.; Clavien, P.A. Cationic longchain ceramide Lcl-30 induces cell death by mitochondrial targeting in Sw403 cells. Mol. Cancer Ther, 2006,
5(6), 1520-1529.

[207] Dahm, F.; Bielawska, A.; Nocito, A.; Georgiev, P.; Szulc, Z.M.; Bielawski, J.; Jochum, W.; Dindo, D.; Hannun, Y.A.; Clavien, P.A. Mitochondrially targeted ceramide Lcl-30 inhibits colorectal cancer in mice. Br. J. Cancer, 2008, 98(1), 98 - 105 .

[208] Modica-Napolitano, J.S.; Aprille, J.R. Delocalized lipophilic cations selectively target the mitochondria of carcinoma cells. Adv. Drug. Deliv. Rev., 2001, 49(1-2), 63-70.

[209] Stover, T.; Kester, M. Liposomal delivery enhances short-chain ceramideinduced apoptosis of breast cancer cells. J. Pharmacol. Exp. Ther, 2003, 307(2), 468-75.

[210] Vlerken, L.E.; Duan, Z.; Seiden, M.V.; Amiji, M.M. Modulation of intracellular ceramide using polymeric nanoparticles to overcome multidrug resistance in cancer. Cancer Res., 2007, 67(10), 4843-4850.

[211] Gómez-Muñoz, A. Ceramide 1-phosphate/ceramide, a switch between life and death. Biochim. Biophys. Acta., 2006, 1758(12), 2049-2056.

[212] Gómez-Muñoz, A.; Frago, L.; Alvarez, L.; Varela-Nieto, I. Stimulation of DNA synthesis by natural ceramide 1-phosphate. Biochem. J., 1997, 325(2), 435-440.

[213] Bornancin, F. Ceramide kinase: the first decade. Cell. Signal., 2011, 23(6), 999-1008.

[214] Munagala, N.; Nguyen,S.; Lam, W.; Lee, J.; Joly, A.; McMillan, K.; Zhang, $\mathrm{W}$. Identification of small molecule ceramide kinase inhibitors using a homogeneous chemiluminescence high throughput assay. Assay Drug Dev. Technol., 2007, 5(1), 65-73.

[215] Graf, C.; Rovina, P.; Bornancin, F. A secondary assay for ceramide kinase inhibitors based on cell growth inhibition by short-chain ceramides. Anal. Biochem., 2009, 384(1), 166-9.

[216] Kim, J.W.; Inagaki, Y.; Mitsutake, S.; Maezawa, N.; Katsumura, S.; Ryu, Y.W.; Park, C.S.; Taniguchi, M.; Igarashi, Y. Suppression of mast cell degranulation by a novel ceramide kinase inhibitor, the F-12509A olefin isomer K1. Biochim. Biophys. Acta., 2005, 1738(1-3), 82-90.

[217] Graf, C.; Klumpp, M.; Habig, M.; Rovina, P.; Billich, A.; Baumruker, T.; Oberhauser, B.; Bornancin, F., Targeting ceramide metabolism with a poten and specific ceramide kinase inhibitor. Mol. Pharmacol., 2008, 74(4), 92532. 